\title{
Harbin ve Kopenhag Opera Binalarının İç ve Dış Mekan Kullanımı Açısından Değerlendirilmesi
}

\author{
Evşen YETIM ${ }^{1 *}$, Mustafa KAVRAZ ${ }^{2}$
}

Öz

Antik Yunan döneminde başlayan tiyatro sanatının Rönesans'ta müzikli oyunlara dönüşmesi ile ortaya çıkan opera sanatı, tarihi süreç boyunca icra edildikleri yapılar açısından kentler ve ülkeler için gücün ve ihtişamın sembolü olmuş, mimari bir imgeye dönüşmüşlerdir. Opera binaları, dünyanın çeşitli ülkelerinden gelen ziyaretçileri ağırlamakta ve bu ziyaretçiler tarafından da mekanın ve sanatın deneyimlendiği simgesel yapılar olarak karşımıza çıkmaktadırlar. Çalışmada, Henning Larsen tarafından tasarlanan ve Danimarka'nın başkenti Kopenhag'ın zengin kültürünü temsil eden Kopenhag Opera Binası ile $M A D^{3}$ Mimarlık tarafından Çin'in Harbin kentinde tasarlanan Harbin Opera Binası'nın iç ve dış mekan kullanımı açısından değerlendirmesi yapılmıştır. İç mekanlardaki fuaye, opera salonu, sahne alanı, prova odaları, sahne arkası birimleri, ıslak hacimler ve sosyal alanlar; tasarım, yapım tekniği ve malzeme açısından değerlendirilmiştir. Bununla birlikte, çalışmaya konu olan opera binalarının kent ve yakın çevresi ile kurdukları ilişki açısından da değerlendirilmesi yapılmıştır.

Anahtar Kelimeler: Opera Binaları, Harbin Opera Binası, Kopenhag Opera Binası

\section{Evaluation of Harbin and Copenhagen Opera Buildings in terms of Indoor and Outdoor Use}

\begin{abstract}
The art of the opera, which started with the transformation of the art of theater, which began in the ancient Greek period into musical plays in the Renaissance, became a symbol of power and splendor for cities and countries in terms of the structures they were performed during the historical period and turned into an architectural image. Opera buildings, welcome visitors from various countries of the world, and they are seen as symbolic structures where space and art are experienced by these visitors. In this study, Harbin Opera House, designed by MAD Architects in Harbin, China; The Copenhagen Opera House, which was designed by Henning Larsen and which represents the rich culture of Copenhagen, has been evaluated in terms of indoor and outdoor use. The foyer, opera hall, stage, rehearsal rooms, wet areas and social areas in the interiors were evaluated in terms of design, construction technique and material. Besides, the evaluation of the opera buildings which are the subject of the study in terms of the relationship they established with the city and its surroundings.
\end{abstract}

Keywords: Opera Houses, Harbin Opera House, Copenhagen Opera House

\footnotetext{
${ }^{1}$ Karadeniz Teknik Üniversitesi, Fen Bilimleri Enstitüsü, Mimarlık Anabilim Dalı

${ }^{2}$ Karadeniz Teknik Üniversitesi, Fen Bilimleri Enstitüsü, Mimarlık Anabilim Dalı

*ilgili yazar/Corresponding author: evsen yetim101@hotmail.com

${ }^{3}$ Ma Yansong tarafindan kurulmuştur.

Gönderim Tarihi: 13.09 .2019

Kabul Tarihi: 24.12.2019
} 


\section{GíRiş}

Tiyatro, opera, bale, konser ve konferans gibi kültürel faaliyetlerin gerçekleştirildiği binalar insanların sosyal hayatları içinde çok önemli bir yere sahiptir. Çok sayıda insanı bir araya toplayan kültürel etkinliklerin gerçekleştirildiği bu binalar; hem fiziksel formlarıyla hem de mimari özellikleriyle inşa edildikleri kentlere değer katmakla birlikte onlara sembolik bir anlam da kazandırmaktadırlar.

Latince "eserler", İtalyanca "1. iş, eser, 2. müzikli dram" sözcüklerinden türeyen "opera" kelimesi ilk olarak "müzikli dram" anlamıla Floransalı müzik kuramcısı Filippo Neri tarafından 1590 yılında kullanılmıştır (URL-1). Greenwald'ın tanımıyla, opera kelimesi İtalyanca 'opera in musica'dan gelmekte olup, "müzikli eser" olarak ifade edilmektedir. Bu bağlamda opera, tiyatro eserinin müzik ve şarkılar eşliğinde izleyicilere sunulması anlamına gelmektedir (Greenwald, 2014, s.1). Operanın özü tiyatroya, tiyatronun özü Antik Yunan dönemindeki Dyonissos şenliklerine dayanmaktadır. Tanrı Dyonissos adına düzenlenen bolluk ve bereketi temsil eden eğlenceler ise ilkel dönem av törenlerine kadar uzanmaktadır. Opera binalarının gelişim süreçlerini incelerken çıkış noktası olan tiyatro binalarının oluşumundan başlamak gerekmektedir (Yener, 1964, s.5). Tiyatro ilk kez M.Ö. 6. yüzyılda, Yunan toplumundaki dinsel törenlerden ayrılarak süreç içinde bir sanat türü haline gelmiş, dinsel ya da pratik ölçütlerle değil, estetik ölçütlerle değerlendirilen bir "oyun"a dönüşmüştür. Ortaçağ'da Hristiyanlık geleneğinden yeni bir tiyatro türetilmiş ve oyun yeri olarak kiliselerin iç mekanları kullanılmıştır. Bu çağ, kilise tiyatrosunun yanı sıra akrobatların, soytarıların, hokkabazların tek kişilik ya da grup halinde yapmış oldukları gösterilerin de hem halk arasında hem de saraylarda ilgi gördüğü bir dönem olmasına rağmen, tiyatroyu yeniden kurallı bir oyuna yani sanata dönüştüren, oyunun yazılı öğesini vurgulayan kilise olmuştur. Bunun ilk örnekleri, Kitabı Mukaddes'ten belli bölümlerin sahne etkileri de gözetilerek seslendirilmesiyle gerçekleştirilmiştir. Bu seslendirme 10. yüzyılda oyuncuların sahne performanslarıyla gerçek bir canlandırmaya dönüşmüştür. Tiyatro sanatı 13. yüzyıldan sonra manastırların dışına yayılmıştır (Yıldız, 2005, s.430). On ikinci yüzyılda kiliselerde başlayan dini tiyatro, on üçüncü yüzyılda Dante ve on dördüncü yüzyılda Petrarch'ın gelişi ile kiliseden pazar yerlerine geçiş yapmıştır (Fuat, 1984, s. 65). Oyunların kiliselerin dışına taşmasıyla, oyunculara hareket serbestisi sağlanmış ve böylelikle mekansal intiyaç ortaya çıkmıştır. Yüzlerce oyuncunun rol aldığı bu tarihin en büyük kitlesel tiyatrosu için de binalarla sınırlanan meydanlar, pazar yerleri kullanılmıştır (Schubert, 1955).

15. yüzyıldan itibaren Roma ve Yunan felsefenin öne çıkması ile yeni bilgiler ışığında bilimde, felsefede ve sanatta ortaya çıkan pek çok yenilik etkisini göstermiştir. Mimari, resim, heykel alanındaki başarılı çalışmalar el işlerini sanat kavramına yükseltirken, sahne sanatları da bu gelişmeden payına düşeni almıştır. Gerek Latince'den çevrilen, gerekse eski biçimlere bağlı hazırlanan oyunlarla aranan heyecan bir türlü yakalanamamıştır. Bu süreçte Machiavelli'nin 1469-1527 arasında yazdığı "Adam Otu" adlı oyunda aralara yerleştirdiği şarkılar o dönem için bir ilk olmuştur. 1471 yılında Poliziano'nun yazdığı "Orfeo" adlı yapıt ile pastorallere ilgi başlamıştır. Yunan eserlerinin şarkılar eşliğinde söylenildiğinin öğrenilmesi üzerine, 1574 yılında bestelerini Marulo'nun hazırlamış olduğu solo ve koro şarkılar eşliğinde bir oyun ortaya konulmuştur. Böylece şarkılı türleri kısa zamanda popülerlik yakalamıştır (Nutku, 1985, s.142). 1607 yılında Gagliani ve Rossi Monteverdi, Orfeo adlı operaları ile orkestrayı ön plana çıkarmış, bunun üzerine ses türlerini zenginleştirirken aryalar doğmuştur. Bu süreçte, 1637 yılında Venedik'te ilk opera binası açılmış, böylece sanatın merkezi Floransa'dan Venedik'e kaymıştır (Yener, 1964, s.11). 
19. yüzyıldan itibaren opera sanatı tüm dünyaya yayılmıştır. 19. yüzyıl ortalarına rastlayan dönemde, kapalı sahneye ayrıca yeni bir yaklaşım getirilmiştir. Sahne önce dört duvarı olan kapalı bir mekan olarak düşünülmüş ve yönetmen oyunun hazırlıkları bittiğinde, oyunun etkisinin hangi yönden daha iyi iletilebileceğine karar verirse, sahneye koyuşta o duvarın kaldırılması planlanmıştır. Endüstriyel buluşların yaygınlaştığı bu dönemde, hava gazının ve ardından elektriğin kullanımıyla aydınlatma alanında oldukça büyük aşamalar kaydedilmiştir. Tiyatro bu yüzyılda en parlak ve görkemli devrini yaşamıştır. Yine bu dönemde rastlanılan bir başka yenilik çağdaş tiyatro ve operalarda görülen seyirci bölümünün karartılmasıdır ki, bu yöntemle sanatçıların sahnede daha iyi konsantre olmaları sağlanmıştır (Yıldız, 2005, s. 435).

20. yüzyılda yepyeni bir mimari kimlik tüm dünyayı etkisi altına alırken sanat mekanları da bundan etkilenmiştir. 20. yüzyılın başlarında beton teknolojisinde yaşanan gelişmeler mimarlara daha özgür tasarım şansı vermiştir. Diğer popüler yaklaşım da sese ışık gibi davranma eğilimidir. Bu nedenle geometrik akustik için tasarlanan yüzeyler oluşturulmuş ve kaynaktan çıkan ses olabilecek en verimli biçimde emici yüzey olan seyirciye ulaştırmaya çalışılmıştır. Başka bir amaç da seyirciyi sahneye olabildiğince yakın yerleştirerek salon boyutlarını küçültmektir (Rossing, 2007, s.15). 21. yüzyılda ise, 20. yüzyıldaki Modernizm üslubunun dayattığı kısıtlamalarının aksine, ortaya konan estetik anlayıştaki değişim ile opera binalarında artan mali yüklerden kaçınılmadığı görülmüştür. Önceki dönemlerde olduğu gibi bu yüzyılda da bulundukları yerlerin yeni yüzleri, sembol binaları olarak, inşa edildikleri kentlere ve ülkelere sembolik değerler katmışlardır. Bu binalar bazen eski değerlere ve mimari tarzlara atıfta bulunurken, bazen de teknolojinin zenginliği ile tamamen geleceğe yönelik özellikler taşımışlardır.

21. yüzyılda dünyanın hemen her yerinde pek çok opera binası yapılmıştır. Mimari görünüşleriyle, teknolojileriyle, işlevleriyle ve formlarıyla sıra dışı olarak nitelendirilebilecek bu binalar, çağımızın dikkat çekici mimari örnekleri arasında yer alamktadır. Zaha Hadid'in Çin'de gerçekleştirmiş olduğu Guangzhou Operası, Snohetta firmasının Oslo'da gerçekleştirmiş olduğu ve çevresiyle etkili bir uyum sağlayan Oslo Opera Binası, Amerika'nın en büyük ikinci kültür merkezi olarak Cesar Pelli tarafından tasarlanan Adrienne Arsht Kültür Merkezi Operası üç ayrı coğrafyaya ait önemli örnekler olarak gösterilmektedir. Tıpkı bu yapılar gibi Harbin Opera Binası ve Kopenhag Opera Binası da tasarlandıkları kent ve ülke için sembolik, anlamsal, ekonomik, kültürel değer taşımaktadırlar. Mimari tasarımın doruk noktaları olarak ortaya çıkan ve oturma birimlerinden, akustik ve aydınlatma bilimlerine kadar son derece gelişkin olan bu binalar; salt estetik olarak değil, akılcı binalar olarak da karşımıza çıkmaktadır.

\section{2. ÇALIŞMANIN PROBLEMI, AMACI VE YÖNTEMI}

21. yüzyılda tam manasıyla kentler hatta ülkeler arasında birer yarış unsuru haline gelen opera binaları oldukça dikkat çekmektedir. Opera binaları sadece inşa edildikleri kentte ya da ülkede yaşayan insanların değil, dünyanın farklı noktalarından ziyaret etmek ve mekanı deneyimlemek isteyen insanların da ilgi odağında bulunmaktadır. İnsanların bir araya gelip sosyalleştikleri, bir performansı ya da mekanın kendi atmosferini deneyimledikleri bu yapıların potansiyeli oldukça dikkat çekmiştir. Bu çalışma kapsamında günümüz gereksinimlerini göz önünde bulundurarak inşa edilen, inşa edildikleri ülke ve kentler için simgesel anlam taşıyarak işaret öğesi olan Harbin Opera Binası ile Kopenhag Opera Binası'nın tasarım süreçlerinin nasıl geliştiği, dış ve iç mekanların hem fiziksel hem de sembolik olarak nasıl anlamlandırıldığı ele 
alınmıştır. Çalışmada bu iki opera binasının tasarım, yerleşim, inşa edilme kriterleri, ç ve dış mekan özellikleri araştırılarak benzerliklerinin ya da farklılıklarının ortaya konularak değerlendirilmesi amaçlanmıştır. Değerlendirmeler; bina yakın çevre ilişkisi, fuaye, salon, sahne, sahne arkası birimlerinin tasarım yaklaşımları kapsamında yapılmıştır.

Çalışmada öncelikle opera binaları ile ilgili genel bir literatür taraması yapılmıştır. Opera binalarının gelişim sürecinin yer aldığı bu tarama sonucunda; 21. yüzyıl opera binalarında teknoloji, form ve malzemenin etkisiyle oldukça dikkat çekici örneklerin orta konulduğu görülmüştür. Bu bağlamda, birbirlerinden oldukça farklı noktalarda tasarlanan Harbin ve Kopenhag olmak üzere iki çağdaş opera binası örneklem olarak seçilmiştir. Yazılı kaynaklardan toplanan bilgiler, toplanan görsel veriler ile birlikte analiz edilmiş ve değerlendirmeler yapılmıştır.

\section{HARBIN OPERA BINASI}

Çin'in Heilongjiang Eyaleti'nin başkenti ve en büyük kenti olan Harbin, Songhua Nehri'nin güney yakası boyunca uzanmaktadır. Çin'in sekizinci büyük kenti olmasının yanı sıra, Kuzeydoğu Çin'in siyasi, ekonomik, bilimsel, kültürel ve iletişim merkezi olarak da dikkat çekmektedir (URL-2). Ülkedeki hızlı kentleşme temposu nedeniyle, kentlerin temel özelliklerinden yoksun, sayısız çarpık ve basit altyapıya sahip yerleşimler ile karşı karşıya kalındığını gören hükümet; bu eksiklikleri tamamlamak için güçlü adımlar atmak istemiştir. Bu nedenle, kente halkın bilimsel, sosyal, kültürel etkinlikler gerçekleştirmesine imkan sağlayacak opera, müze, kütüphane, vb. mimari yapıların tasarlanması için mimarları teşvik ederek yarışmalar başlatmıştır (URL-3), (Şekil 1). Başlatılan bu önemli adımla, "Harbin Cultural Island" (Harbin Kültür Adası) temasıyla Songhua Nehri boyunca bir master planın oluşturulması için 2010 yılında uluslararası yarışma düzenlenmiştir. Yarışma kapsamında peyzaj alanı, opera binası ve kültür merkezini içeren bir proje öngörülmüştür (Şahin, 2015). Ülkenin kalkınmadan sorumlu yetkilileri; "Harbin'in kendi DNA'sını ve kültürel mirasını yansıtan, kuzey Çin'in güçlü, sağlam ve dinamik sanatsal karakterini vurgulayabilen kentin en önemli simgesi" olabilecek bir binanın tasarlanmasını istemişlerdir (Worrall, 2016). Açılan yarışmayı kazanan MAD Architects (Şahin, 2015) Harbin Opera Binası'nı tasarlarken, provokatif olmayı, ülkede kullanılan mimarlık diline meydan okumayı, sanat, kültür ve peyzaj entegrasyonunu sağlamayı hedeflemişlerdir (Şekil 1). MAD Architects'e göre Çin'de tasarlanan projelerin çoğunda masaya yeni bir şey getirmekten ziyade başka yerlerden görülüp alınan tasarımların tekrarı söz konusu olduğu için, Onlar mimarların ve mimarlığın toplumu şekillendirmeye yardımcı olma sorumluluğunu güçlü bir şekilde hissederek; mimarlığın algı ve çevrelere meydan okuması gerektiğine inanmışlardır (URL-3). Bu nedenle tasarladıkları projenin kent ve kentlinin kültürel ve sosyal belleğinde yer edinebilmesine oldukça önem vermişlerdir.
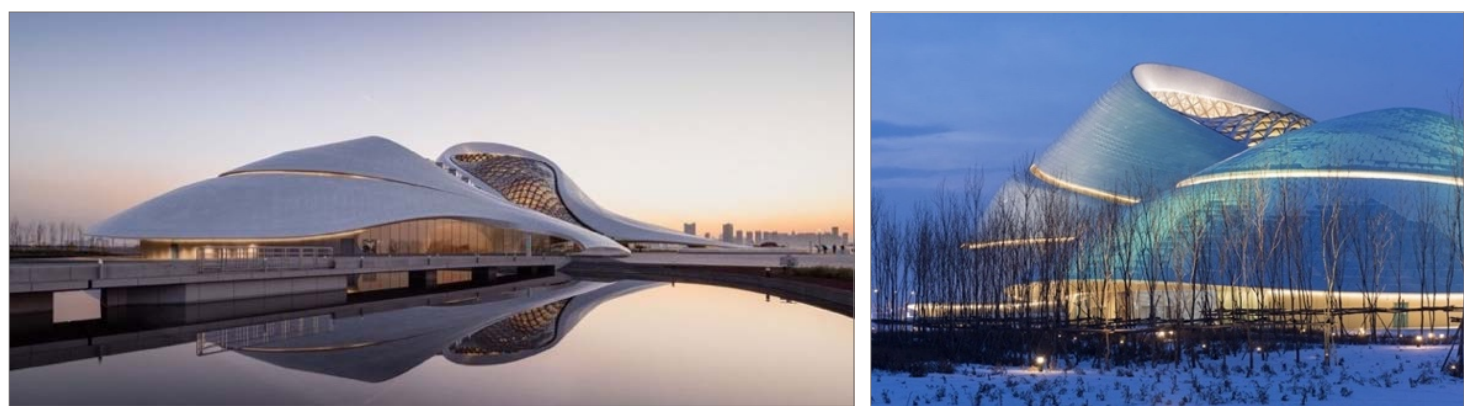

Şekil 1. Harbin Opera Binası'nın sembolik ve heykelsi formu (URL-4, URL-5) 
Rus sınııına birkaç yüz kilometre kadar yakın olan ve neredeyse altı ay boyunca karla kaplı olan Harbin kenti, dünyanın en büyük Buz ve Kar Festivali'ne ev sahipliği yapmaktadır. 4.5 milyon nüfuslu Harbin kentinin kuzeyinde bulunan 177 hektarlık Sun Adası'nda gerçekleştirilen kültürel etkinliğe dünyanın farklı noktalarından insanlar katılmaktadır. MAD Architects binayı tasarlarken buranın bir kar kenti olduğunu ve tasarımın da kar kaplı kültür adası ile bütünleşmesi gerektiğini düşünmüşler ve Harbin Kültür Adası'nda opera binası ile birlikte içinde restoran, otel ve sergi mekanının bulunduğu ek bir bina daha tasarlamışlardır (URL-4). Bu bağlamda, tasarım konsepti olarak seçtikleri "donan müziğin ritmini aydınlatmak" ilkesiyle yola çıkan tasarım ekibi, Harbin'in buz tutmuş manzarasına da cevap vermek istemişlerdir (URL-6). Dolayısıyla Harbin Opera Binası, doğadan ilham alan, yerel kimlik, kültür ve sanatın bir araya geldiği bir mimariyi ifade etmektedir. Bina, hem opera ve tiyatro performansları ile hem de peyzaj içindeki simgesel duruşu ile halkın çevre ile olan duygusal ve görsel bağını derinleştirmektedir (URL-7), (Şekil 2).

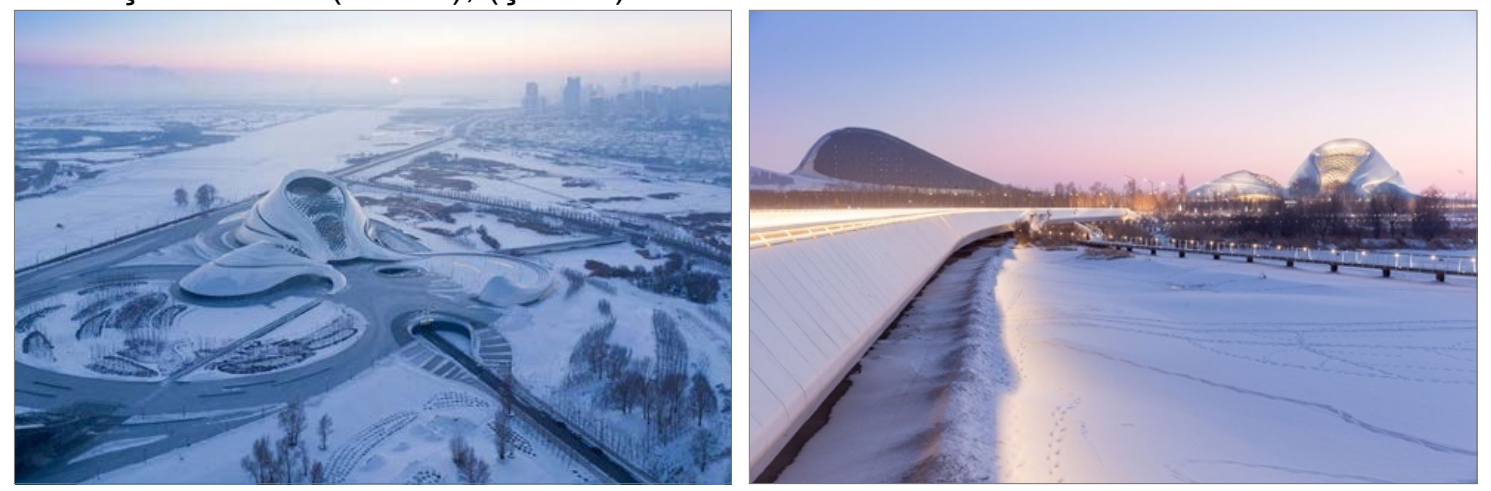

Şekil 2. Harbin Opera Binası'nın “donan müziğin ritmini aydınlatmak” konsepti (URL-5)

Buz kenti Harbin'in siluetinde yeni bir dönüm noktası olarak görülen Harbin Opera Binası'nın inşa edilmesiyle, kente ikonik bir bina kazandırılmıştır. Bina, Harbin kentinde, sulak bir alanın ortasında, kentin kuzey bölgesinin vahşi ruhuna ve soğuk iklimine cevap verecek şekilde inşa edilmiştir. Suyun ve rüzgarın şekillendirdiği izlenimini veren bina; çevresindeki doğa ile son derece uyumlu bir birliktelik sergilemektedir. MAD Architects'in kurucusu Ma Yansong'a göre Harpin Opera Binası; geleceğin kültür merkezi olarak hayal edilmiş büyük bir performans alanı, aynı zamanda da; insan, sanat ve kent kimliğinin bütünleşmesini sağlayan, bunları doğaya katan dramatik bir kamusal alan olarak ifade edilmiştir (Bilgiç, 2018). Organik forma sahip opera binası, Harbin Kültür Adası'nın odağında yer almakta ve yaklaşık $1.796 .804 \mathrm{~m}^{2}$ olan toplam arazide $80.000 \mathrm{~m}^{2}$ alan kaplamaktadır. İçerisinde 1600 koltuklu büyük bir tiyatro salonu ve 400 kişilik daha küçük bir tiyatro salonu bulunmaktadır (Şahin, 2015).

Açık hava etkinlikleri ve performanslar için tasarlanan ve kamusal alan içinde yer alan bina, biri büyük, diğeri daha küçük iki salon ve büyük bir kamusal plaza olmak üzere üç farklı odak alanına sahiptir (URL-8). Opera binası ve plazanın iç mekanlarını oluşturan temel yapı ile otopark, betonarme sistem ile inşa edilmiştir. Betonarme mekanlar binaya organik form kazandıracak olan uzay kafes sistem ile kaplanmıştır. Fuaye alanı ve salonlarda geniş açıklıkların geçilmesine izin veren uzay kafes taşıyıcı sistem, beyaz alüminyum malzeme modülleri ile kaplanmıştır (Garber, 2017, s. 130), (Şekil 3). 

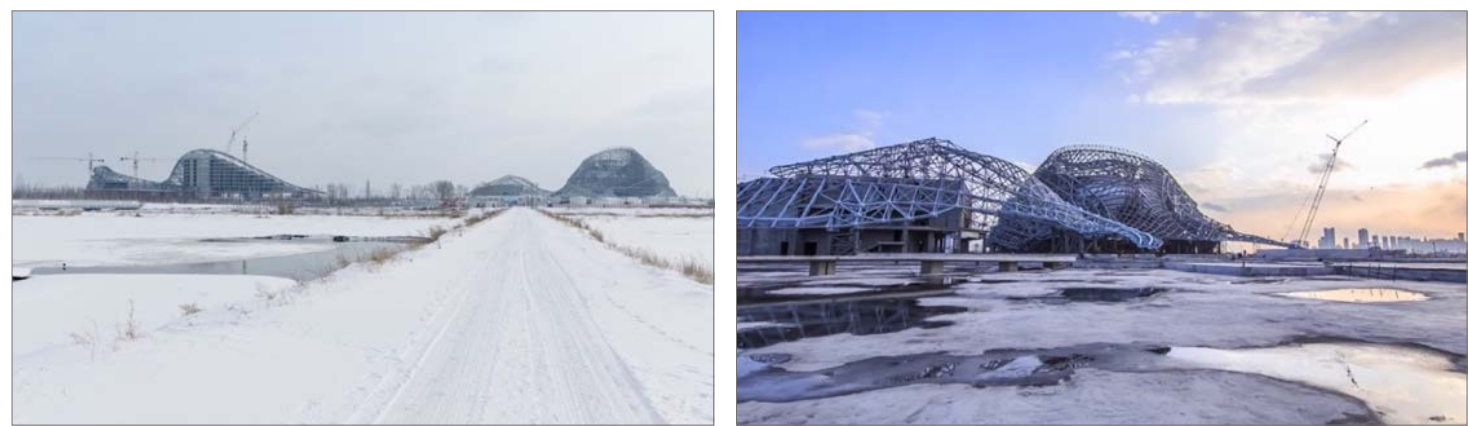

Şekil 3. Binanın uzay kafes sistem ile oluşturulmuş konstrüksiyonu (URL-9)

Kültür adasındaki üç bina formu, beyaz alüminyum panellerden oluşan dalgalı bir yüzeyle birbirlerine bağlanmaktadır. Dış cephedeki bu pürüzsüz doku bazı noktalarda alüminyum malzemenin kabartılmasıyla desteklenerek cephe yüzeyindeki dinamik etki güçlendirilmiştir (URL-8). Binanın zeminde devam eden duvarlarında beyaz alüminyum panellerle uyum sağlayan beyaz taş ve beton kullanılmıştır. Böylece binanın konsepti olan buz ve kar etkisi güçlendirilmiştir (URL-9), (Şekil 4).
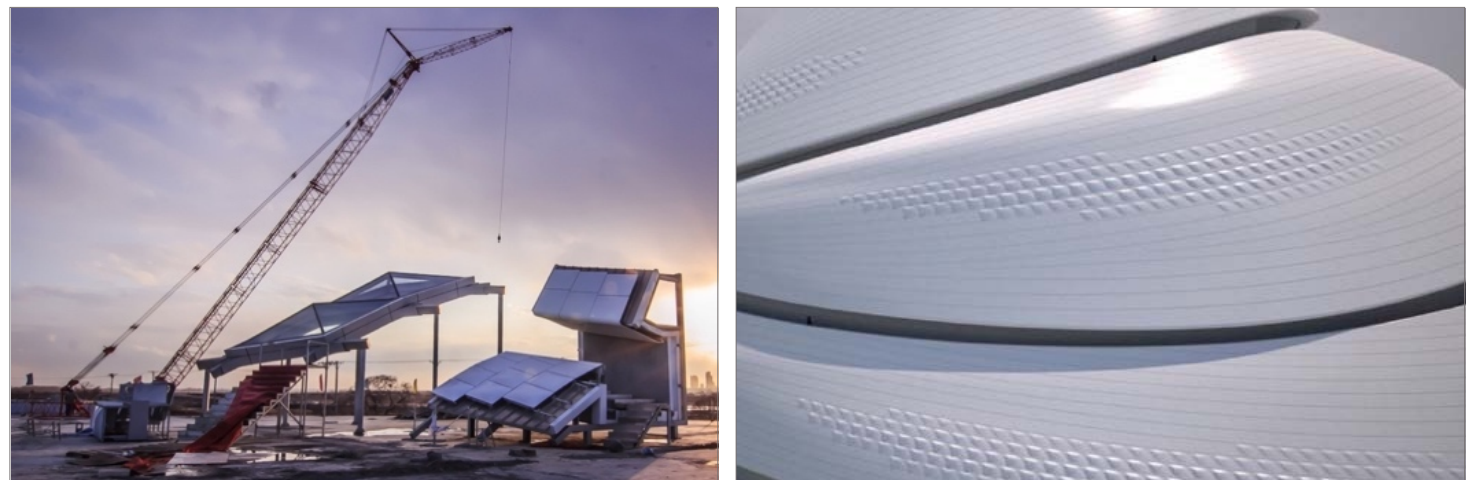

Şekil 4.Uzay kafes sistem üzerine monte edilen beyaz alüminyum kaplama (URL-9)

Salonların bulunduğu formlarda, fuaye alanlarına gün ışığının girmesini sağlayan tavan ışıklıkları tasarlanmış ve çatı bir dizi cam piramit ile örtülerek opera binasına kışı çağrıştıran bir görünüm kazandırılmıştır. Binanın dış cephesinde yer alan ve içeri doğru oyulmuş izlenimi veren kıvrımlı yollar, zeminden 35 metre yükseklikteki binanın zirvesinde bulunan seyir teraslarına çıkmak için tasarlanmıştır. Halkla etkileşimi ve binaya katıımı en üst düzeye çıkarmak amacıyla binanın zirvesinde hizmet veren açık ve kapalı bu gözlem platformları, ziyaretçilerin kent siluetini ve kültür adasının etrafındaki sulak alanların panoramik manzaralarını izlemelerine olanak sağlamaktadır (URL-8), (Şekil 5).
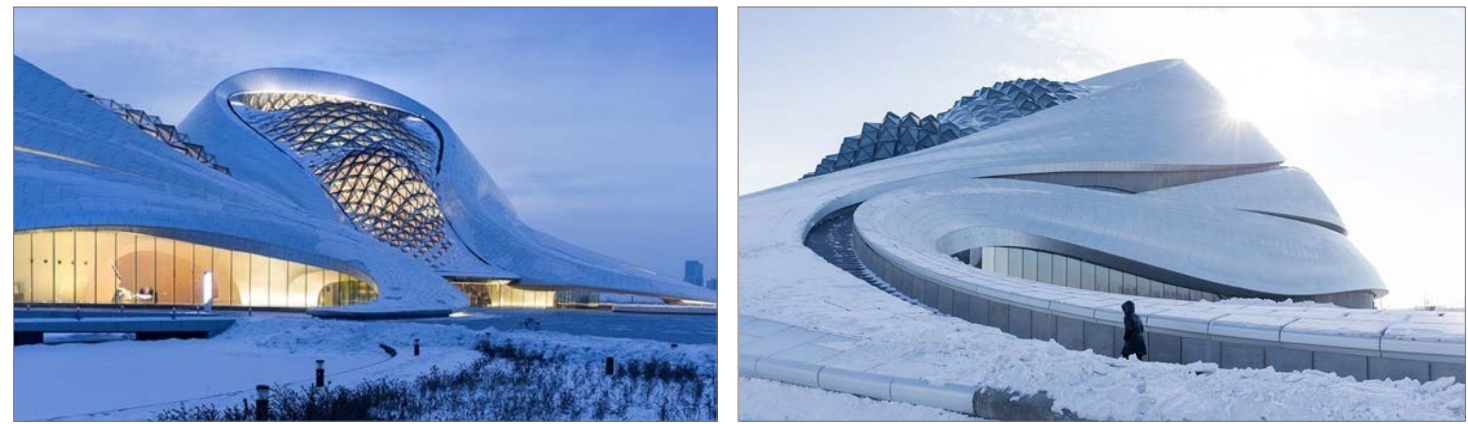

Şekil 5. Buz izlenimi veren cam piramit çatı ışıklıkları ve gözlem platformları (URL-5) 


\subsection{Bina, kent ve yakın çevre ilişkisi}

Opera binaları kentler ve ülkeler için kültürel ve sosyal buluşma noktalarıdır. Bu nedenle bu binaların, hem kent ve yurtiçinden hem de yurtdışından katılım sağlayacak ziyaretçiler için kolay ulaşıllabilir olması oldukça önemlidir. Harbin Opera Binası güneyde Songhua Nehri kuzeyde ise yapay oluşturulmuş göl ve göletlerle kentten tamamen koparılmış Harbin Kültür Adası'nın batısında yer almaktadır. Güneyinde pek çok alana ev sahipliği yapan Sun Adası ve özellikle Harbin Buz ve Kar Sanatları Sergi Salonu, güneybatısında Yueliangwan Dianshicheng Golf Sahası, kuzeydoğu'sunda Siberia Tiger Park bulunmaktadır. Harbin kentine havayolu, demiryolu ve karayolu ile erişim sağlanmaktadır. Kent merkezinden yaklaşık $40 \mathrm{~km}$ uzaklıkta bulunan Harbin Taiping Havaalanı'ndan sağlanan ulaşımda otobüs ve metro hatları bulunmaktadır. Özellikle metro seferleri havalimanının içine kadar devam etmektedir ve ulaşım zamanı açısından otobüs seferlerine göre oldukça kısadır. Harbin Opera Binası kent merkezindeki Shimao Avenue Metrosu'suna $3 \mathrm{~km}$ mesafededir. Opera binasına buradan otobüs seferleri düzenlenmektedir (Şekil 6).
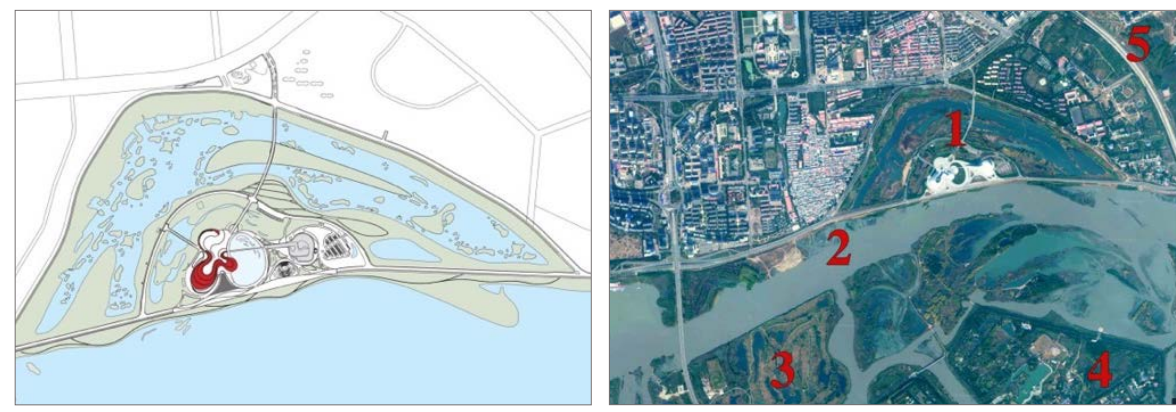

1. Harbin Opera Binası

2. Songhua Nehri

3. Yueliangwan Dianshicheng Golf Sahasi

4. Harbin Buz ve Kar
Sanatları Sergi Salonu

5. Siberia Tiger Park

Şekil 6. Harbin Opera Binası Ulaşım Şeması (URL-10)

MAD Ekibi, tasarladıkları akışkan formu kimi zaman binanın çatısı, kimi zaman binanın duvarı, kimi zaman ise yürüyüş yolları, merdivenler olarak işlevlendirerek binayı topoğrafyanın organik hareketleri ile buluşturmuşlardır. Planın ortasında yapay bir göl bulunmaktadır. Birinci binanın eğimi zemine yaklaştıkça, formun en tepe noktasından alçalarak devam eden yüzey bir kamusal meydan haline gelmekte, su üzerinde bir köprüye dönüşmekte ve ikinci binayı şekillendirmek üzere yeni bir form oluşturmaktadır. Çevredeki sulak alanlarda bulunan zemin tasarımları ziyaretçiler ve balıkçılar için yürüyüş yolları ve platformlar sağlamaktadır. Bu açık, yarı açık ve kapalı kamusal mekanlarda halkın kullanımına sunulmuş park, yürüyüş ve piknik alanları da bulunmaktadır (Garber, 2017, s. 132), (Şekil 7).

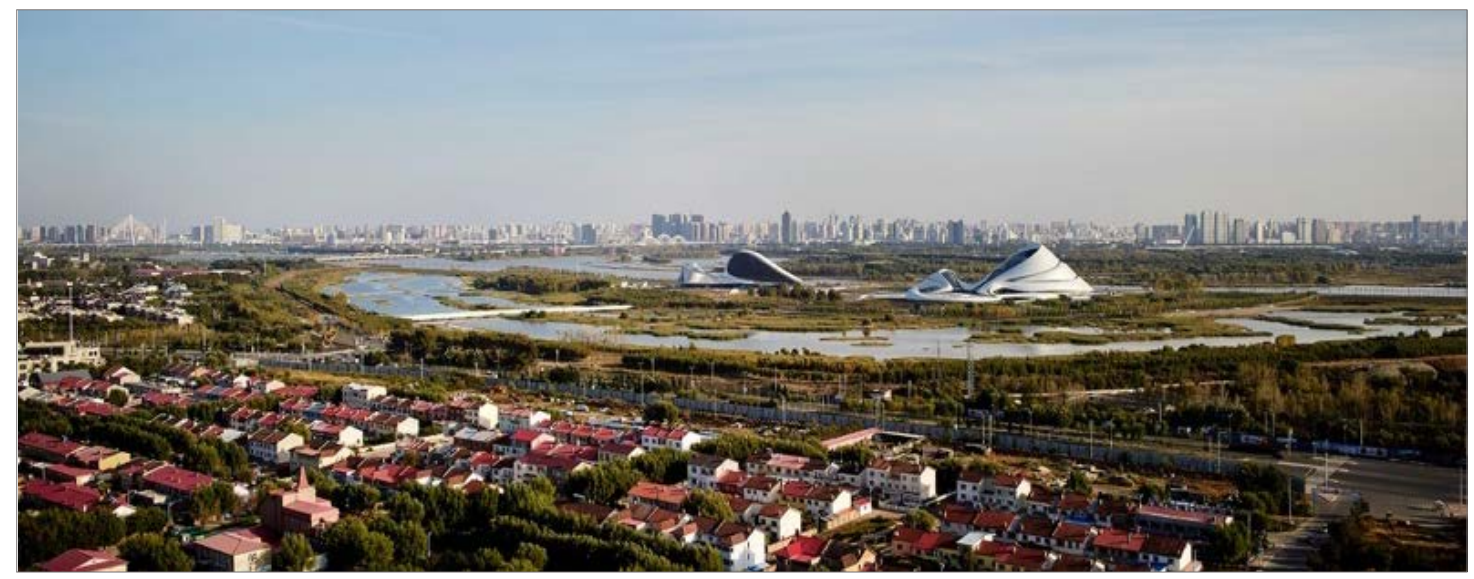

Şekil 7. Kuzeybatı yönünden Harbin Opera Binasına panoramik bakış(URL-11) 


\subsection{Opera binasındaki iç mekanlar}

Harbin Opera Binası genel olarak üç bölümden oluşmaktadır. Vaziyet planı üzerinden okunabilir olan bu bölümler hacimsel olarak büyükten küçüğe doğru; büyük opera salonu, küçük tiyatro salonu ve bilet satış ofisidir. Büyük opera salonu ve küçük tiyatro salonunun bulunduğu formların iç mekanlarında; fuaye alanı, hizmet birimleri, seyirci ile sahne alanı, sahne teknik birimleri, sahne arkası birimleri, prova odaları, ıslak hacimler, kafe ve restoran bulunmaktadır.

Binanın güney cephesinden zemin altında tasarlanan kapalı otoparka araç girişi verilerek merdivenler ile birlikte otoparktan ana avluya ulaşım sağlanmaktadır. Ziyaretçiler bu noktadan sonra avludaki bilet ofisinden bilet satın alabilmekte, opera izleyebilmekte ya da opera binasını ziyaret edebilmektedirler. Ana salonun bulunduğu form, tiyatro salonunun bulunduğu formun neredeyse dört katı büyüklüğünde tasarlanmıştır. İki salon arasındaki geçiş, esnek bir planlama ile tasarlanan lobi aracılığıyla sağlanmıştır. Dış formda mevcut olan dinamik ve organik hareketler, mekan içerisinde özellikle lobi bölümünde korunmuştur. Islak hacimler birinci katta, opera ve tiyatro salonlarının iki yanında kolay ulaşılabilir ve gizli bir planlama ile tasarlanmıştır. Binaya, zemin katının altında bulunan bodrum kattan ve birinci katın bazı noktalarından servis girişi sağlanmaktadır. Bodrum katta bulunan girişler, özellikle salonların sahne dekorlarının taşınmasında, depo ve teknik birimlerin kullanılmasında oldukça önem taşımaktadır. Sahne dekorları bu girişlerden asansörler yardımıyla sahneye ulaştırılmaktadır (Mollard, 2015), (Şekil 8).

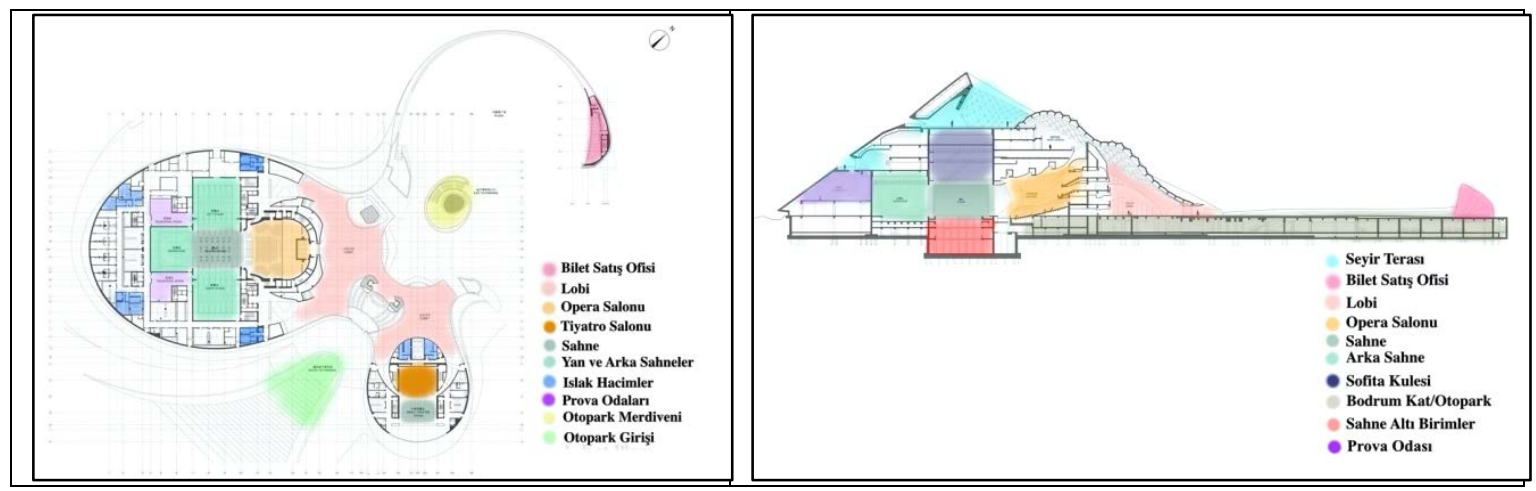

Şekil 8. Harbin Opera Binası birinci kat planı ve opera salonu kesiti (URL-7)

\subsubsection{Ana fuaye}

Harbin Opera Binası'nın kuzey cephesindeki geniş kapılardan kamusal kullanıma sahip olan kapalı alana girilmektedir. Ana giriş, opera salonunun bulunduğu büyük fuaye alanına açılmaktadır. İkinci giriş ise ana girişten daha küçük olmakla birlikte tiyatro salonunun bulunduğu küçük fuaye alanına açılmaktadır. Fuaye alanında dış kabuğun renk ve form olarak iç mekana yansıması görülmektedir. Kabukta seyir terasına ulaşmayı sağlayan rampalar, oluşturdukları yarıklar ile fuaye alanında ferah bir atmosfer yaratmıştır.

Binanın iç mekanları, planın gerçek inceliğini oluşturmaktadır. Fuayede, hem yan duvardan hem de kristal üçgen tepe camından içeri sızan ışık, heykelsi merdivenler ile fuaye alanında zarif ve güçlü bir mimari etki oluşturmaktadır. Fuayeden opera salonuna ulaşmak için kullanılan organik formlu bu heykelsi ahşap kaplama merdiven rengi ve ahşap malzemenin birleştirilme tekniğinden oluşan dokusuyla da dış kabukla uyum sergilemekte ve onun iç mekandaki akışkanlığının devamı niteliğinde kendini 
göstermektedir (Garber, 2017, s. 135). Ahşap merdiven kabuğu, fuayenin odak noktasını oluşturmaktadır. Yukarıdan aşağıya süzülürken adeta ortamı yıkayan ışık tüm fuayeye sıcak ve davetkar bir atmosfer kazandırmaktadır (Şekil 9). Dışarıdaki gölgeliklerde bulunan yarıkların içine yerleştirilen spot lambalar, yansımadan kaçınmak ve içeriden dışarının görülebilmesini sağlamak amacıyla zemine doğru yönlendirilmiştir (URL-6).
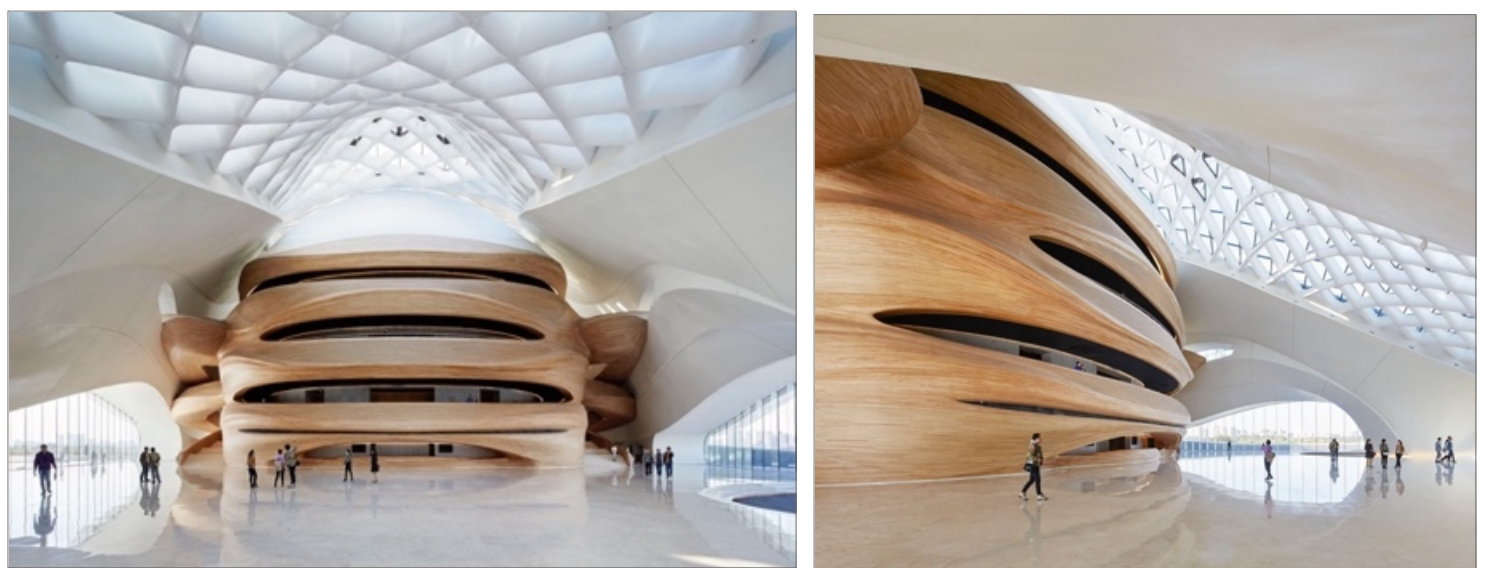

Şekil 9. Harbin Opera Binası fuaye alanı ve heykelsi ahşap merdivenler (URL-11)

Mekandaki "saf", "duru" atmosferin deneyimlenmesi adına tasarım ekibi ziyaretçilerin armatürleri değil ışığı ve yarattığı etkiyi görmelerini istemişlerdir. Bu bağlamda, teknik detaylar tarafından engellenmeyen, keskin köşeler ya da spotlar tarafından kesintiye uğratılmayan ışığın güzel ritmi ortaya çıkarılmıştır. Projenin aydınlatma tasarımıyla, katılımcıların mekanı ve müziği daha güçlü deneyimlemeleri için mimarideki duruluğu, şeffaflığı ortaya çıkartmanın yollarını bulmak amaçlanmıştır (URL-6), (Şekil 10).
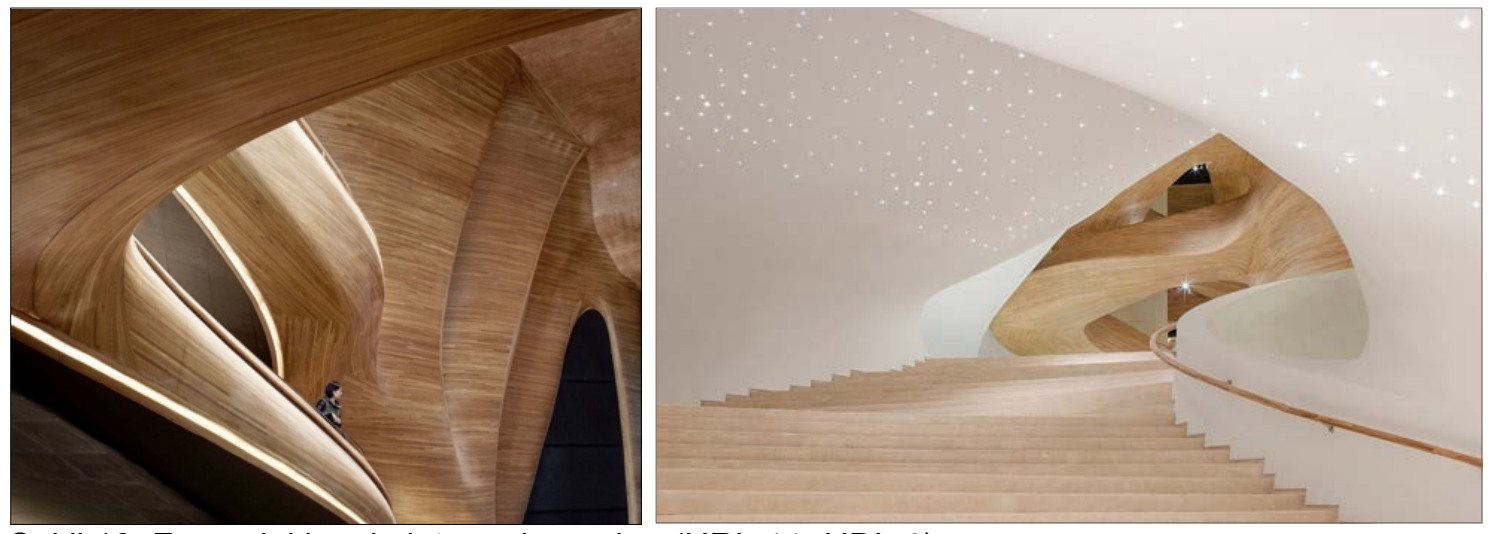

Şekil 10. Fuayedeki aydınlatma elemanları (URL-11, URL-6)

Piramit cam çatının üzerinde kristal bir etki yaratmak isteyen tasarımcı; her bir üniteyi noktalı filmle birleştirmiştir. Gün ışığı da her piramidal üniteye parlaklık katmakta ve gün içinde farklı ışık oyunları oluşturmaktadır. Geceleri de görsel bir şölen oluşturan opera binasının, filmlenmiş camları içeriden ışıldayan ve uzaktaki ziyaretçilerin dikkatini çeken led ışık çubuklarıyla donatılmıştır (URL-9), (Şekil 11). 

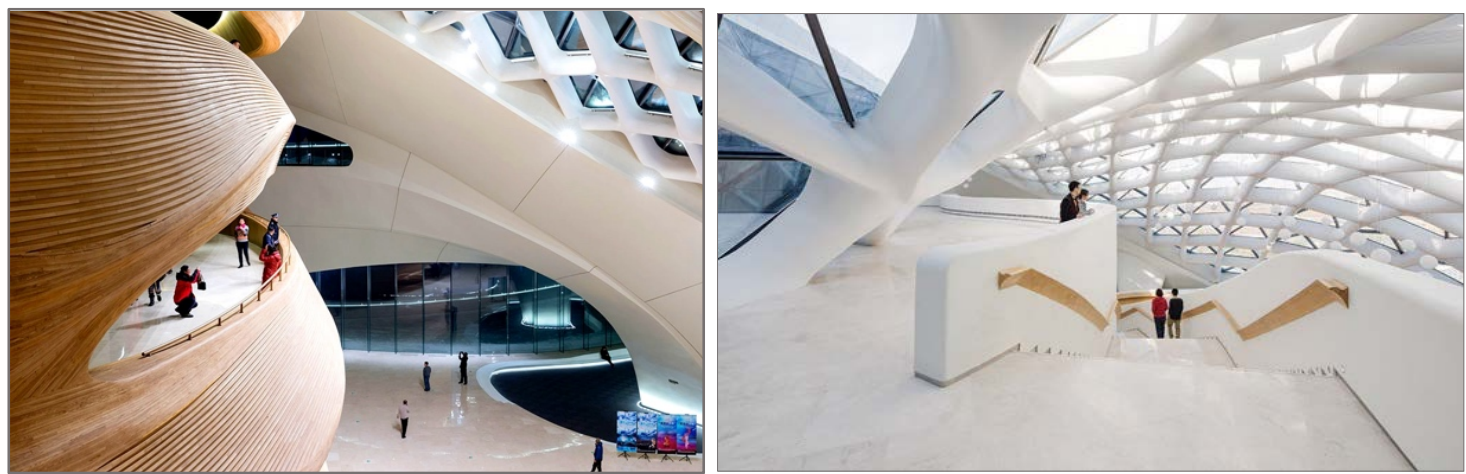

Şekil 11. Fuaye alanının üzerini örten piramidal çatı ışıkıkları (URL-5, URL-3)

\subsubsection{Opera salonu}

Fuayede karşılaşılan heykelsi merdivenleri saran ahşap kaplamanın, içerisinde de devam etmesiyle gösterişli bir şekilde ziyaretçilerini karşılayan ana salon 1600 kişi kapasitelidir. Zarif ahşap kompozisyon, salonun zeminine ulaşmadan önce pek çok organik kıvrım ile balkon katlarını çevrelemektedir (Şekil 12). Salonun bu eğrisel hatları arasında yumuşak bir geçiş sağlanmış ve formun iç bükey ve dış bükey yüzeyleri ile mekanın akustik koşulları da düşünülmüştür. Oldukça ince bir işçilikle, yaklaşık 50 zanaatkarın dört ay boyunca çalışmasıyla ortaya çıkan ahşap konstrüksiyon opera salonunda sahnelenecek yapıtlar için de nitelikli bir mekan sağlamıştır. Oditoryumun içinde bulunan teknik birimler organik konstrüksiyon sayesinde zarif bir şekilde gizlenmiş ve görsel bütünlük sağlanmıştır. Salonun oturma alanı, daha samimi bir deneyim sağlayabilmek için bir dizi küçük kabine bölünmüştür. Salonun arka tarafında, doğal ışığın girebilmesi için açılabilir küçük bir pencere yer almaktadır (Mollard, 2015).
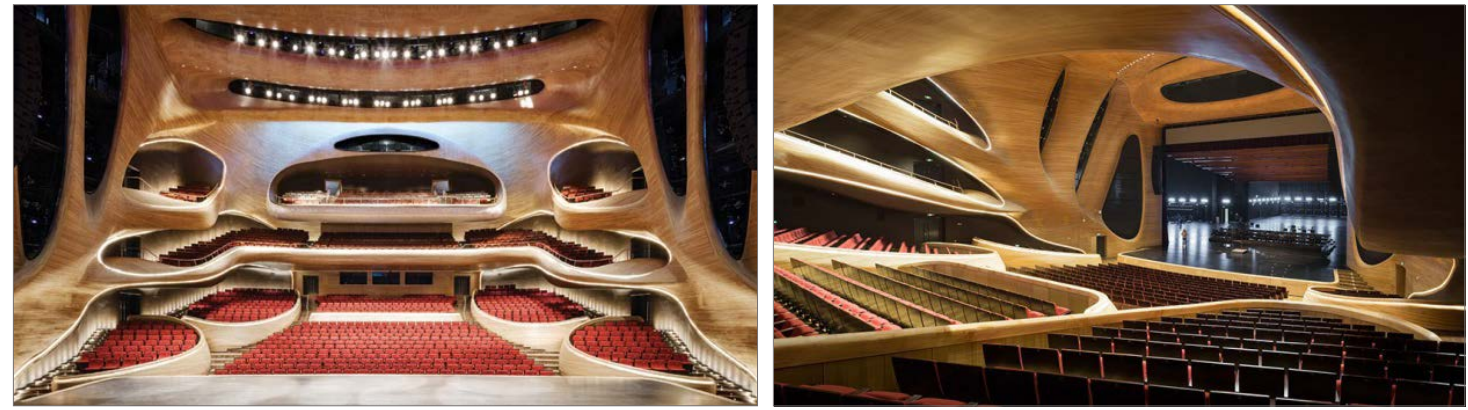

Şekil 12. Salonun seyirci oturma alanından görünümler (Garber, 2017; URL-5)

Büyük opera salonunda tasarım ekibi, asma katın üstündeki VIP seyircileri için parlayan bir "elmasa" karar vermiştir. Özel led armatürler, sahnede sergilenecek esere ya da mevsime göre değişen akrilik elmas panelin arkasına gizlenerek yaldızlı beyazdan sıcak amber rengine geçişleri sağlanmıştır. Bu yaldızlı, parlak elmas yaklaşımı; zemindeki otopark bölümünü ve ana fuayeyi birbirine bağlayan koridorda da tekrar etmiştir. Fiber optik aydınlatma merdivenlerde rüya gibi, yaldızlı, büyük bir giriş etkisi yaratmıştır. Tasarım ekibi ana salonun aydınlatılması için üç yol ortaya çıkarmış ve bir hiyerarşi geliştirmiştir. Fuaye girişinde yer alan ışık matı, ortada dolaylı bir ışık, fuayenin sonundaki ahşap kabukta ise dikey bir parlaklık ziyaretçileri karşılamaktadır. Tüm ışık elemanları mimari mekanın içinde gizlenmiş durumdadır (URL-6) (Şekil 13). 

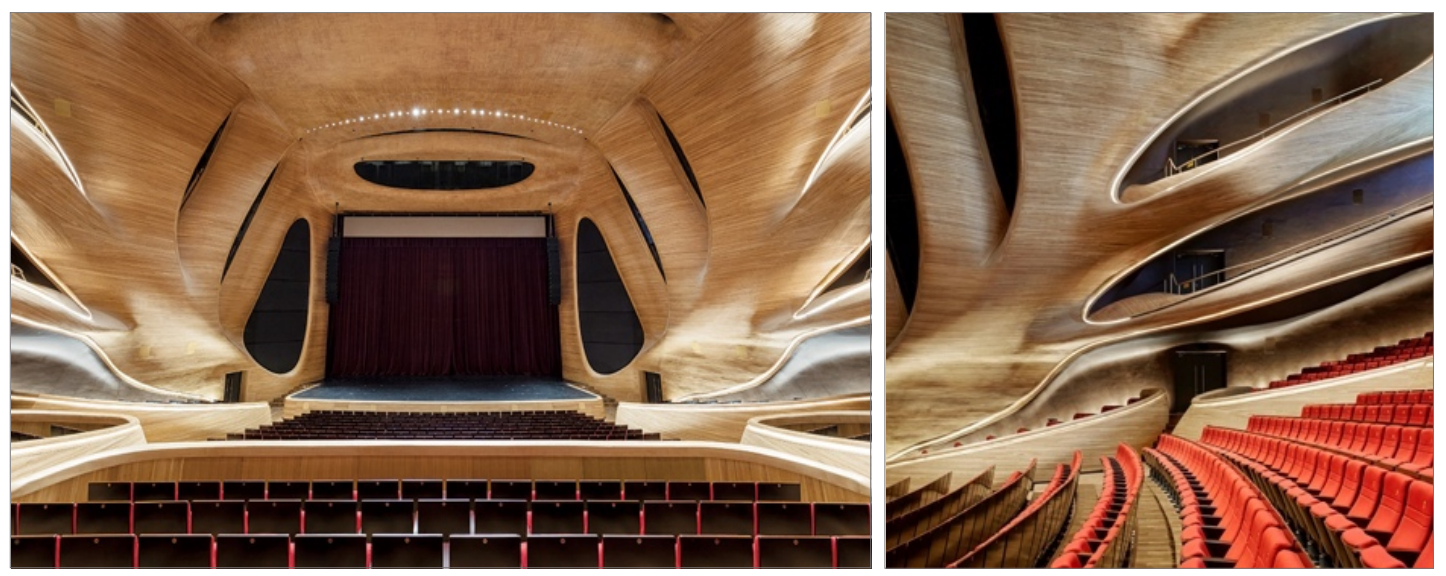

Şekil 13. Opera salonu aydınlatma elemanları (URL-3, URL-11)

400 kişilik küçük tiyatro salonunda ise sahnenin arkasındaki panoramik pencere sayesinde binanın dışı sahnenin bir parçası gibi algılanmaktadır. Sahne tasarımı sadece batı operası ve modern drama gösterileri için değil, aynı zamanda geleneksel Çin tiyatrosu oyunları için de kullanılabilecek donanımda tasarlanmıştır (URL-9) Göl ile kurulan kesintisiz bağlantı, iç mekanın duvarlarında gölün etkisini taklit eden yüzeylerle sağlanmıştır. Farklı noktalardan yansıyan ışık ile ortaya çıkan dalga efekti, duvarlara dikkatlice yerleştirilen nişli yüzeyler ile oluşturulmuştur. Duvar dokusu drama, ritim ve hoş gölgeler yaratırken ışıkla birlikte hareket etmektedir (URL-6), (Şekil 14).
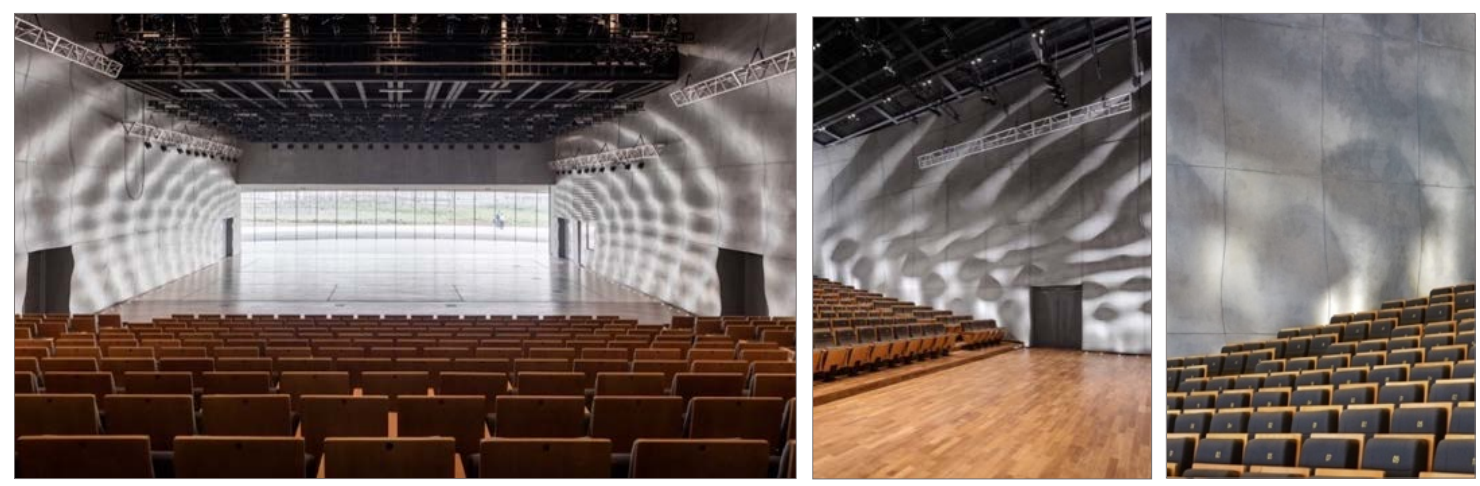

Şekil 14. Harbin Opera Binası küçük tiyatro salonu (URL-7)

\subsubsection{Sahne alanı}

Harbin Opera Salonunun sahne alanı; performansın gerçekleştirildiği ana sahne, iki adet yan sahne ve bir adet arka sahneden oluşmaktadır. Ana sahnenin üstünde yer alan sofita kulesi, sahne alanında gerçekleştirilecek olan performansın içeriğine göre konumu değiştirilebilen aydınlatma ve diğer teknik elemanlar ile donatılmıştır. Sahnenin hemen altında yer alan depo birimlerinden asansörler yardımıyla sahne dekorlarının taşınması sağlanabilmektedir (Şekil 15). 


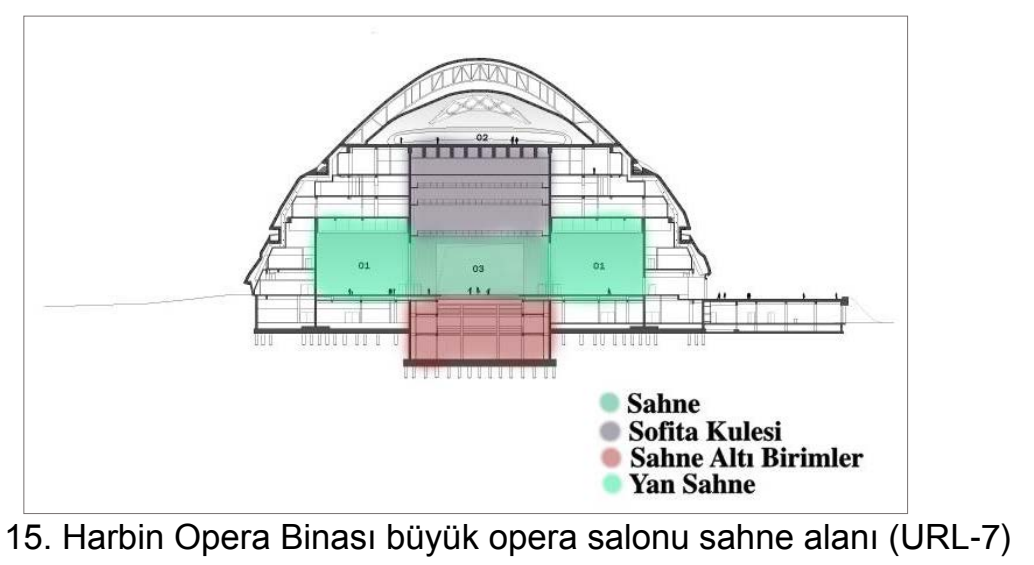

Küçük salonun sahne alanında doğal ışık potansiyel bir aktör rolü üstlenmektedir. Sahnenin hemen arka duvarı, manzaranın panoramik bir görüntüsünü sunmaktadır. Bu durum sahne tasarımcılarını iki ortam arasındaki sınırla oynamaya teşvik etmiştir. Sahne henüz tasarım aşamasındayken, MAD Architects cam panelin tamamen açılmasını istemiş fakat bütçe sınırları nedeniyle bu fikirden vazgeçilmiştir (URL-3). Sahnenin arkasındaki manzara sahne performansının bir parçası niteliğinde düşünülebilmektedir. Tıpkı modernizm döneminde sahnelerin arka planları için tasarlanan ve seyirci için görsel bir etki yaratılması istenen üç boyutlu yüzeyler, hareketli dekorlar gibi bu göletin Harbin Opera Binası için farklı bir deneyim sunacağı düşünülerek geçmişe atıf yapılmıştır.

\subsubsection{Sahne arkası birimleri}

Opera binasının zemin katında yan sahnelere bitişik olarak tasarlanmış iki adet prova odası bulunmaktadır. Asma katta ise zemin kattaki prova odalarının yaklaşık üç katı büyüklüğünde üçüncü prova odası tasarlanmıştır. Bu büyük prova odası çatının organik formu nedeniyle iç mekanda eğrisel bir yüzeye sahiptir. Hem duvar hem çatı olan bu eğrisel yüzey delikli ahşap paneller ile kaplanmıştır. Çatı örtüsünün bir bölümünde açılan yırtık sayesinde gün ışığının mekana girmesi sağlanmıştır (Şekil 16).
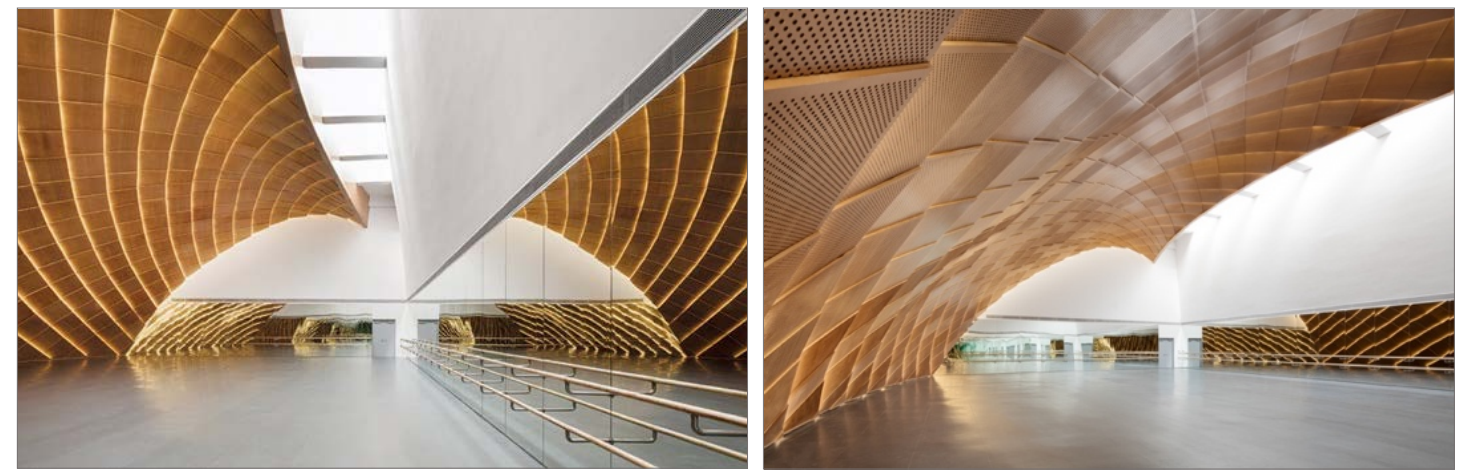

Şekil 16. Opera binasının asma katında bulunan prova odası (URL-3, URL-9)

\section{KOPENHAG OPERA BINASI}

Başkenti Kopenhag olan Danimarka'nın ana dili İsveç ve Norveç diline yakın olan Danca'dır. Danca'da "koben" kelimesi "tüccar", "havn" ise "liman" olup København "ticaret limanı" veya "tüccar limanı" anlamına gelmektedir (URL-12). Liman kenti olması ile ün kazanan Kopenhag için 2000 yılında, Henning Larsen'in tasarım ofisinin de dahil olduğu üç mimarlık firması kent limanının gelişme olanakları üzerine bir çalışma 
yürütmek üzere görevlendirilmiştir. Henning Larsen Architects, 2000 yılının öncelikle ilk çeyreği için kente dinamik kültürel bir zarafet getirmek amacıyla iç liman alanı için konut, ticaret ve büyük kültürel tesislerden oluşan bir konsept proje sunmuştur. Bu projedeki fikir, aynı zamanda hem liman için hem kent için büyük bir yeni kültürel tesis sağlamak isteyen Kopenhag nakliye şirketi A.P. Maersk MC Kinney Møller tarafından da desteklenmiştir (Karlson, 2011). Liman kentinin denizle olan bağını güçlendiren Kopenhag Opera Binası ya da kısaca Operaen, neo-fütürist tarzda bu proje kapsamında tasarlanmıştır (Şekil 17). 2000-2004 yılları arasında süren inşaat, 500 milyon doların üzerindeki maliyetiyle o dönem binaya dünyanın en pahalı opera binası ünvanını kazandırmıştır. Ocak 2005'te, resmi olarak açılmış olan bu sanat ve performans merkezi Danimarka Ulusal Operası'na ev sahipliği yapmaktadır (URL-13). On dört katından beşi zeminin altında bulunan bina toplamda 41.000 metre karedir (URL-14). Kraliyet Tiyatrosu tarafından kullanılan opera binası, büyük çaplı opera ve bale gösterilerine ev sahipliği yapmaktadır (URL-15). İşverenin isteği üzerine Olafur Eliasson, Per Arnoldi ve Per Kirkeby binanın iç mekanlarını tasarlamak üzere görevlendirilmiştir (URL-16).
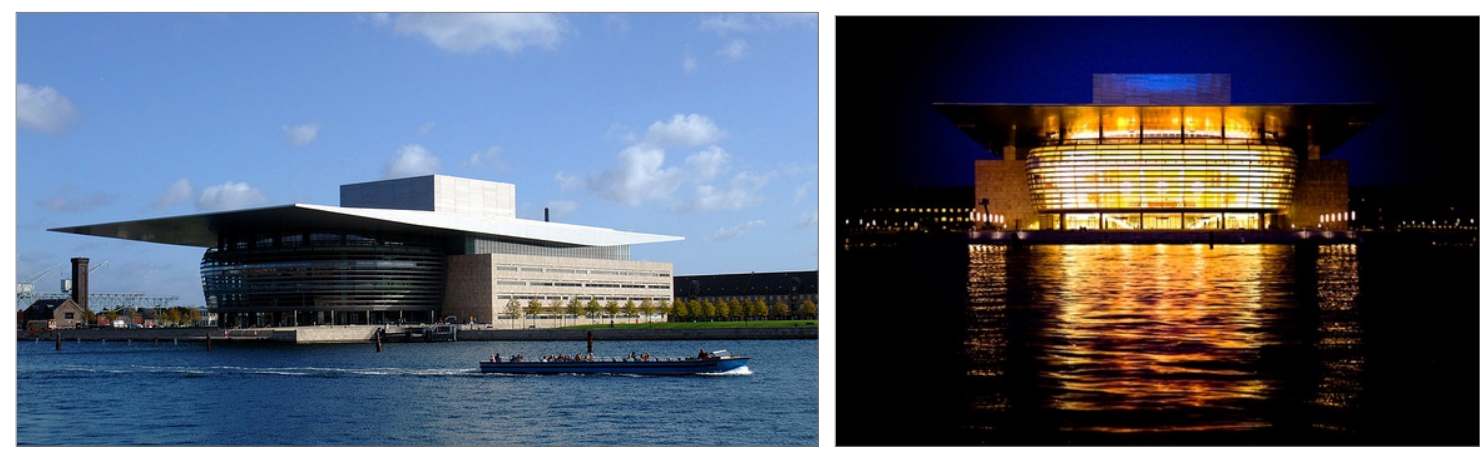

Şekil 17. Kopenhag Opera Binası (URL-17)

Çağdaş bir teknikle tasarlanmış plaza üzerine 32 metre uzunluğunda sundurma eklenmiştir. Sundurma, plazanın üzerine zarif bir şekilde süzülmüş gibi bir izlenim vermekle birlikte zemindeki geniş bir açıklıkla çatıdaki küçük bir yapısal derinliği birleştirmeyi başarmıştır. Mühendisler ana oditoryumda, akustiğin kalitesinden ödün vermeden ziyaretçi konforunu sağlamak için hesaplamalar yaparak bir dizi simülasyon gerçekleştirmiştir. Akustik tasarımın en ince detaylarına kadar dikkat edilen opera birasında, akçaağaçların akıcılığı ve füme meşenin iç mekanla uyumlu tasarımı, ziyaretçilerde dev bir telli enstrümanın içinde oturma hissi uyandırmaktadır (URL-18), (Şekil 18).
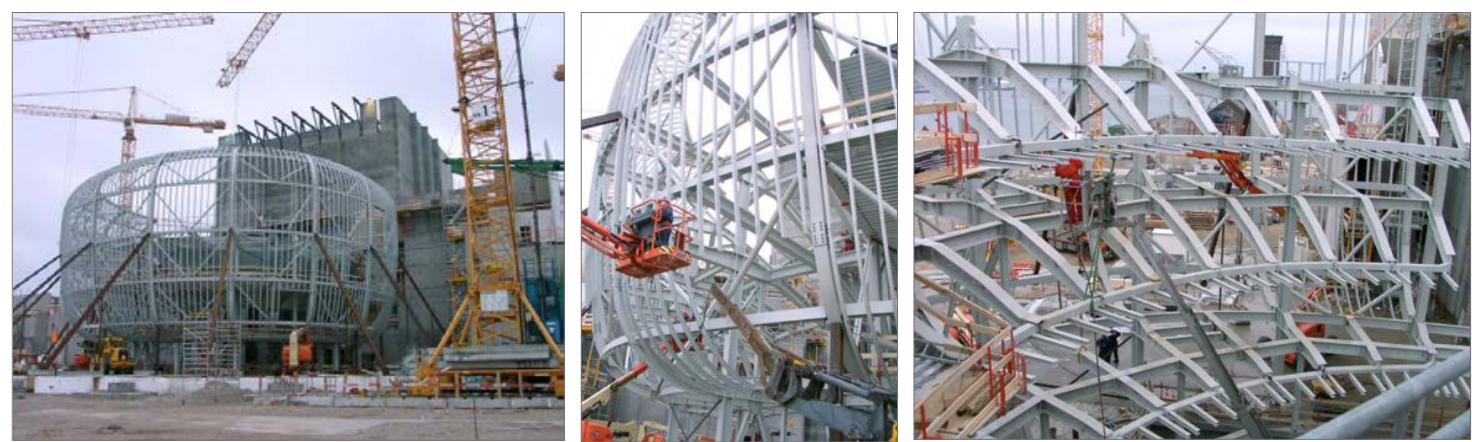

Şekil 18. İş̧a edilme aşamasında, içine opera salonunun yerleştirileceği kabuk (URL-19)

\subsection{Bina, kent ve yakın çevre ilişkisi}


Danimarka'nın kültür ve ekonomi merkezi olan, ayrıca tarihi dokusu çok iyi bir şekilde korunan Kopenhag, aynı zamanda İskandinavya ülkelerinin en güzel kentlerinden biridir. Renkli sokakları, şatoları, kaleleri, rıhtımlarıyla dünyanın her köşesinden insanın ziyaret etmek istediği yerler arasındadır. Kente ulaşımın çok alternatifli oluşu ve kent içindeki ulaşım rahatlığı Kopenhag kentine yapılan seyahat sayısını arttırmaktadır. Bu anlamda, Kopenhag kentine havayolu, demiryolu, deniz yolu ve karayolu ile ulaşmak mümkündür. Kentin güney eteklerinde bulunan Kopenhag Havalimanı kent merkezine yaklaşık $12 \mathrm{~km}$, Kopenhag Opera Binası'na ise yaklaşı $17 \mathrm{~km}$ uzaklıkta bulunmaktadır. Havalimanından opera binasına ulaşım metro ve otobüs seferleri ile sağlanmaktadır. Kentin merkezinde ve Tivoli Lunaparkı'nın hemen karşısında bulunan Kopenhag Merkez Tren İstasyonu kent dışından ya da kentin uzak noktalarından merkeze gelmek isteyen ziyaretçiler için oldukça rahat ve kolay bir ulaşım sunmaktadır. Kopenhag Opera Binası'na Havnebussen hattı üzerinde bulunan iki noktadan feribot ile ulaşım sağlanmaktadır. Bunlara ek olarak kent merkezinde bulunan Yeni Kral Meydanı'ndan yola çıkarak Inderhavnsbroen Köprüsü üzerinden gerçekleştirilebilecek kısa bir yürüyüşle de Kopenhang Opera Binası'na ulaşmak mümkündür (Şekil 19).
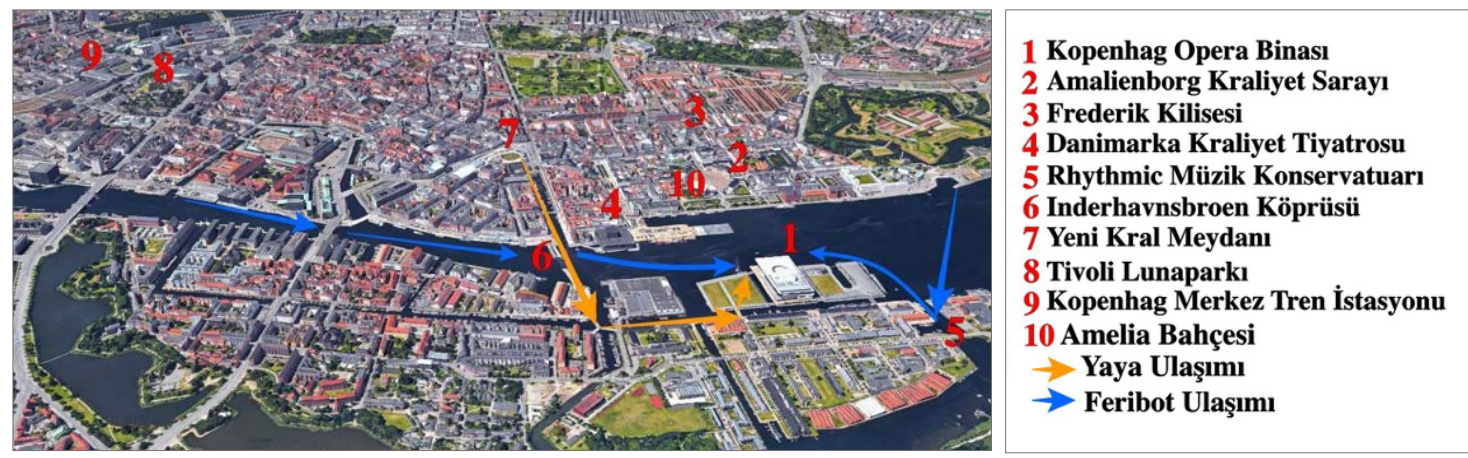

Şekil 19. Kopenhag Opera Binası'na ulaşım şeması (URL-20)

Opera Binası, Kopenhag Limanı'ndaki Dock Adası'nda yer almaktadır. Frederik Kilisesi ile aynı aks üzerinde bulunan Amalienborg Kraliyet Sarayı'nın tam karşısında, Danimarka Kraliyet Tiyatrosu'nun da tam çaprazında bulunmaktadır (URL-15). Opera binasının dış cephesi Güney Alman Jura sarı kireç taşı ile, koridorlar ve fuaye alanı ise Sicilya Perlatino mermeri ile kaplanmıştır (URL-14). Binanın 32 metre uzunluğunda konsol çıkan göz alıcı çatısı çok uzaklardan görülebilmektedir ve binanın estetik çekirdeğini oluşturmaktadır. Limanın etrafındaki canlı atmosfer ve oditoryumun heykelsi, içe dönük kabuğu arasındaki etkileşim, gerilim ve heyecan yaratmaktadır (Karlson, 2011). Binayı her iki taraftan çevreleyen, 17 metre genişliğindeki peyzajlı su kanalları ile dinlenme alanları tasarlanmıştır. Bu yeni kanallar, adanın üzerinde tasarlanan Kopenhag Opera Binası'nın yerleşimini de vurgulamaktadır (URL-15). Ziyaretçiler adaya; ya tekneyle ya da büyük gezinti yolunu kullanarak ulaşırken, opera binasına akşamları batan güneşin etkisinin hissedildiği büyük ön avlu tarafından karşılanmaktadırlar. Ziyaretçilerin kentin muhteşem manzarasının tadını çıkarabileceği bu çok amaçlı meydanda halka açık bir kafe de yer almaktadır. Royal Theatre, bu meydanı bir su kenarı sahnesi içeren performans alanı olarak kullanmaktadır (Karlson, 2011). Binanın ön tarafı görsel olarak liman alanına entegre edilmiştir. Sahne arkası birimlerin tasarlandığı binanın arka tarafı ise binanın kuzey ve güney tarafında planlanan yeni apartman bloklarıyla iyi ilişki kurmuştur (URL-15) (Şekil 20). 

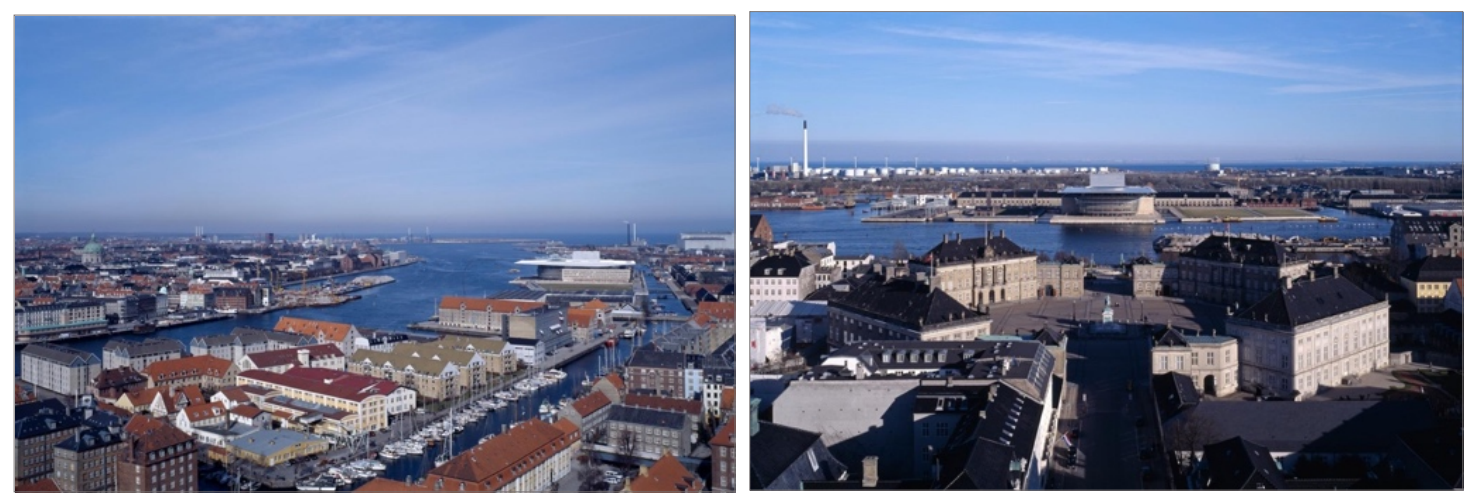

Şekil 20. Kentin farklı noktalarından opera binasının görünümü (URL-21)

\subsection{Opera binasındaki iç mekanlar}

Opera binası genel olarak farklı faaliyetlere imkan tanıyan; restoran ve kafenin de bulunduğu fuaye alanı, opera ve tiyatro sanatlarının sergilendiği ve izlendiği salonlar ile sahne alanı, sahne alanını destekleyen sahne arkası birimlerden oluşmaktadır (Şekil 21). Opera binasının girişi kuzeybatı cephesinde tasarlanmış, saydam-opak bölücüler ve merdivenlerle kademeli olarak fuaye alanına açılmıştır. Fuaye ve oditoryum binanın ön kısmında; ıslak hacimler ve vestiyerler fuaye alanının sağ ve sol uçlarında; küçük bir kafeterya da fuaye alanının içinde tasarıma dahil edilmiş; sahne, kulisler, kostüm üretim tesisleri, sanatçı, solist, orkestra ve bale için yönetim birimleri binanın arka bölümünde yer alacak şekilde tasarlanmıştır (Karlson, 2011).
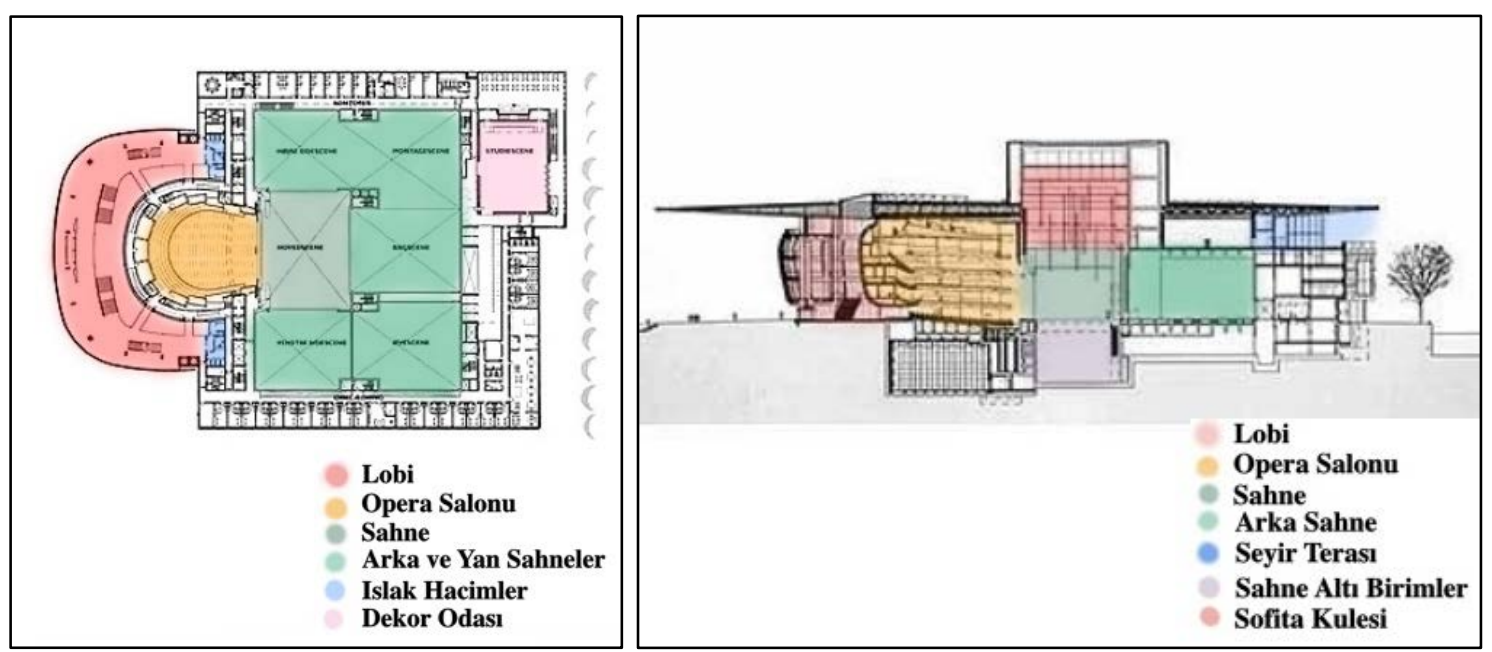

Şekil 21. Kopenhag Opera Binası plan ve kesiti (URL-15, URL-22)

\subsubsection{Ana fuaye}

Kopenhag Opera Binası'nın girişi Amalie Bahçesi'nin tam karşısında yer alan ve tamamen camla kaplı olan kuzeybatı cephesinde bulunmaktadır. Camla oluşturulmak istenen görsel hafiflik duygusu cam cepheyi tutan yatay ve düşey metal çerçevelerin ölçü ve ritimleri ile oldukça başarılı bir şekilde sağlanmıştır. Binanın zemin katındaki girişe kanal manzarası eşlik etmektedir. Ana salonu oluşturan kabuk formu, malzemesinin rengi ve parlaklığı ile birlikte özellikle gece görüntülerinde, cam cepheden çok etkili bir şekilde algılanmaktadır. Binanın kamusal bir mekan oluşu şeffaflığı ve kentle kurduğu görsel bağ ile birlikte desteklenmektedir. 
Giriş cephesinin asal geometrisinin aksine içeride "conch" olarak adlandırılan ve fuayede yüzüyormuş izlenimi veren salonun dinamik ve organik forma sahip heykelsi kabuğu, fuaye içerisindeki doluluk boşluk dengesini sağlayarak hem iç mekan hem de dış mekanda oluşan görsel etkiyi güçlendirmektedir. Sıcaklık hissi veren akçaağaç kaplı dış duvarlar, fuayenin kavisli camına ve çelik cephesine karşı keskin bir tezatlık oluşturmaktadır (URL-14). Fuaye alanıyla bağlantılı balkonlar, koridorlar ve özellikle çatıdaki restoran sayesinde ziyaretçiler kent ve liman manzarasını etkili şekilde izleyebilmektedirler (Şekil 22).
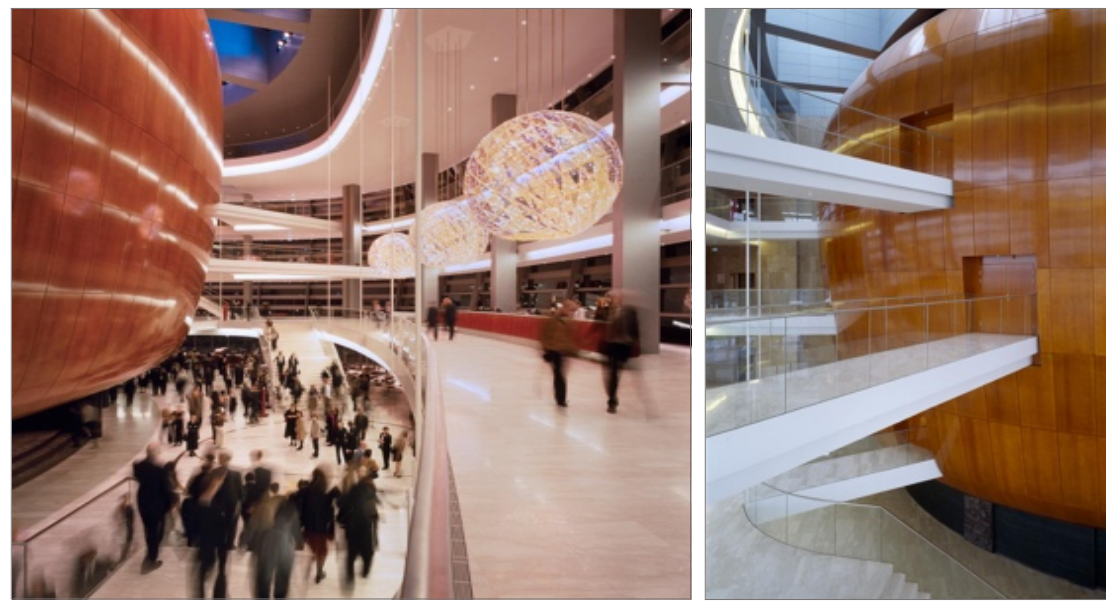

Şekil 22. Fuaye alanına bakış, Conch'un algılanışı (URL-21)

Opera binasının fuaye alanı; oturma birimleri, danışma, kafeterya-restoran, sirkülasyon alanları ve ıslak hacimlerden oluşmaktadır. Opera binası, aynı anda hem kamusal alanı hem de yarı kamusal mekanları bir arada barındırmaktadır. Özellikle opera gösterilerine katılım zorunluluğu olmadan ziyarete açık olan fuaye alanı tüm ziyaretçilere hizmet sunmaktadır. Opera salonuna köprülerle ulaşımı sağlayan fuaye alanı dört kat boyunca yükselmektedir. Aydınlık bir hacme sahip olan fuaye alanı içerisinde hareket eden ziyaretçiler büyük merdivenlerden balkonlara ulaşabilmektedirler. Balkonlar ise dar köprülerle birbirine bağlanmaktadır. Balkonlarda ya da köprülerde ilerleyen ziyaretçiler galeriyi farklı açılardan farklı perspektiflerde algılama deneyimi yaşayabilmektedirler. Balkon katları birbirine cephe tarafından düşey yapı elemanları ile bağlanırken galeri tarafında çelik halatlarla bağlanmaktadır. Köprülerin ve balkon katlarının parapetlerinde cam malzeme kullanılarak galeri boşluğunda görsel bütünlüğün sağlanmasına özen gösterilmiştir (Şekil 23).
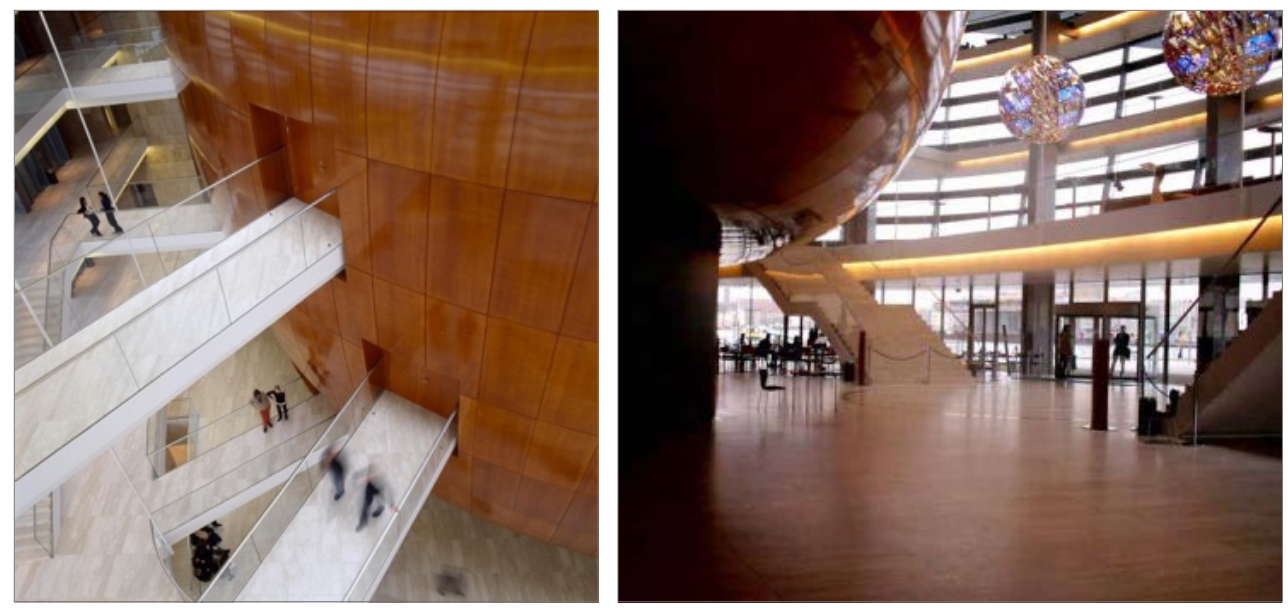

Şekil 23. Fuaye ile opera salonunu birbirine bağlayan dar köprüler (URL-21, URL-23) 
İzlandalı tasarımcı Olafur Eliasson fuaye için 2.000 adet cam ve 300 lambadan oluşan 3 adet aydınlatma heykeli tasarlamıştır (URL-16) (Şekil 24). Mekanda kristalize bir görsel etki yaratan heykeller lineer aydınlatma elemanları ile birlikte akçaağaç kaplı salon kabuğu ve mermer zemin kaplaması üzerinde yansıma oluşturarak mekana ayrı bir dinamizm katmıştır. Giriş katında bulunan ana fuaye ve balkonlarda hakim olan beyaz renk mekandaki ferahlık hissini güçlendirmektedir. Fuayenin ana tavanı üzerindeki çatı ışıklığı cam malzeme ile kaplı olup gün ışığının içeri girmesini sağlamaktadır (Şekil 24). Ayrıca bu çatı ışıklığı, gece oluşan aydınlatma sayesinde kentin başka noktalarından bakıldığında bina içinde bir kristal parlıyormuşçasına renkli bir efekt de oluşturmaktadır.
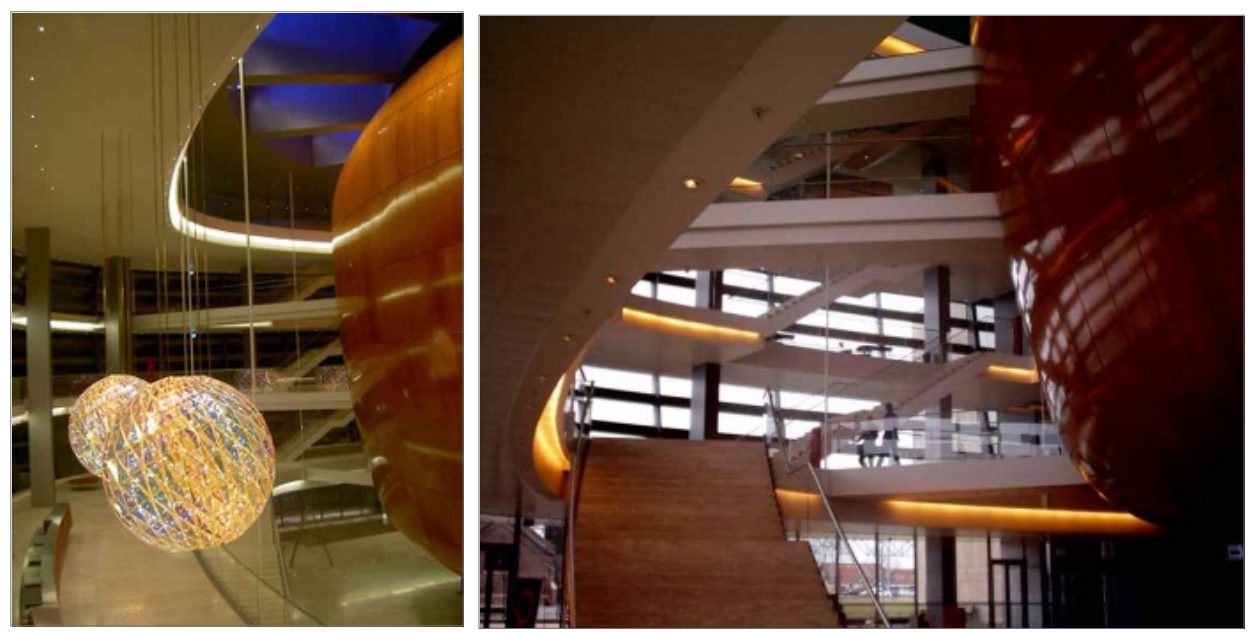

Şekil 24. Fuayedeki heykelsi aydınlatmalar, Gün ışığı kullanımı (URL-23)

\subsubsection{Opera salonu}

Salon, göz kamaştırıcı, yuvarlak ve parlak kabuk biçimiyle içinde mistik bir dünyayı gizleyen salyangoz görüntüsünü anımsatmaktadır. Vernikli ahşap yüzeyleri ve diğer iç yüzey malzemeleriyle birlikte salon, içinde herhangi bir sanat etkinliği gerçekleştirildiği anda devasa bir enstrüman izlenimi uyandırmaktadır. Salon, sahnesi ve dik şekilde yükselen katmanları ile klasik bir yerleşime sahiptir. Sanatsal performansların seyirciye sunulması sırasında seyirciler ile sanatçılar arasındaki görsel ve işitsel iletişimin kalitesine oldukça dikkat edilmiştir (Karlson, 2011), (Şekil 25).
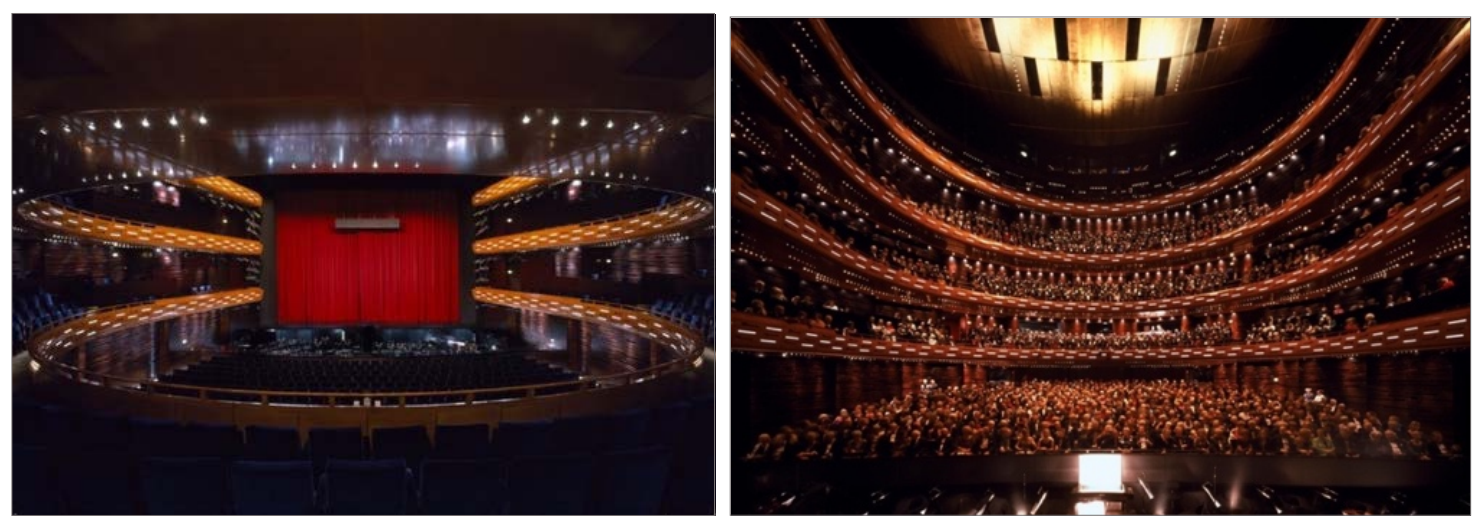

Şekil 25. Kopenhag Opera Salonu (URL-23, URL-21) 
Kopenhag Opera Binası'nın salonu, orkestranın büyüklüğü de göz önünde bulundurulduğunda yaklaşık 1800 kişilik kapasiteye sahiptir. Geleneksel at nalı planlı ana salon üç balkon katına sahiptir ve balkonlar geriye doğru yaslanmaktadır. 419 metrekarelik salonun tavanı 24 karat altından 1.5 kilogram altına eşdeğer olan 105.000 adet levhayla kaplanmıştır (URL-13). Salonun balkonlarında açık renk akçaağaç, duvarlarında koyu renk akçaağaç, zemininde ise meşe kullanılmıştır. Balkonlardaki dekoratif ışık bantları, akustik koşullar göz önünde bulundurularak tasarlanmıştır (URL15). 1800 kişilik kapasiteden daha fazla koltuğun ses kalitesine ve mekanın optimum akustik değerine zarar vereceği belirlendiğinden dolayı kapasite bu sayı ile sınırlı tutulmuştur (URL-24). Binanın iç mekan iklim kalitesinin yüksek standartlarda tasarlanması için nitelikli modüler klima sistemi kullanılmıştır. Böylece özellikle opera salonunda havalandırma sistemi nedeniyle oluşan gürültüler ortadan kaldırılmış olup, iç mekanın ideal koşullarda olması sağlanmıştır (URL-24). Opera binasının aynı zamanda kalbi de olan ana salon, opera ve bale eserleri dışında oyunlar ve müzikaller için gerekli artistik teknik sistemler ile de donatılmıştır.

Opera binasının logosu ve sahne perdeleri Per Arnoldi tarafından, oditoryum katının tepesindeki 4 adet bronz rölyef ise Per Kirkeby tarafından tasarlamıştır (URL-16). İnce uzun dikdörtgen panellerin altından yayılmakta olan ışıklar opera salonunun aydınlatmasında oldukça önem taşımaktadır. Balkon katlarının parapetleri dışbükey şekilde tasarlanarak bombeli bir form kazandırılmış ve yüzeyleri belirli modül boyutta üretilmiş akçaağaçlarla sıralı bir şekilde kaplanmıştır. Salon duvarları panel panel tasarlanarak ve çok parçalı ahşap kaplamalar arasında boşluklar bırakılarak çıkıntılı bir yüzey oluşturulmuş, sesin çarptığı yüzey alanı arttırılarak reverberasyon süresinin düşürülmesi amaçlanmıştır (Şekil 26). Akçaağaç modülleri arasına yatay bant şeklinde led aydınlatma elemanları yerleştirilerek tavanın ortasında bulunan zarif led aydınlatmalardan oluşan ışık kümesinin etkisi güçlendirilmiştir. Kademeli balkonların sayıları ve konumları ses düzenine göre belirlenmiş, salonu kullanan kişi başına düşen alan ve hacim bu şekilde optimum seviyede tutulmuştur. Düz lacivert kumaşla kaplanmış koltukların yerleşim düzeni her birinin sahneyi rahatlıkla görebileceği biçimde tasarlanmıştır. Her bir üst balkon kata çıkıldığında basamakların rıht yüksekliğinde artış yapılmıştır. Koltukların koyu tonu ile salonun amber rengi arasında denge sağlanmıştır.
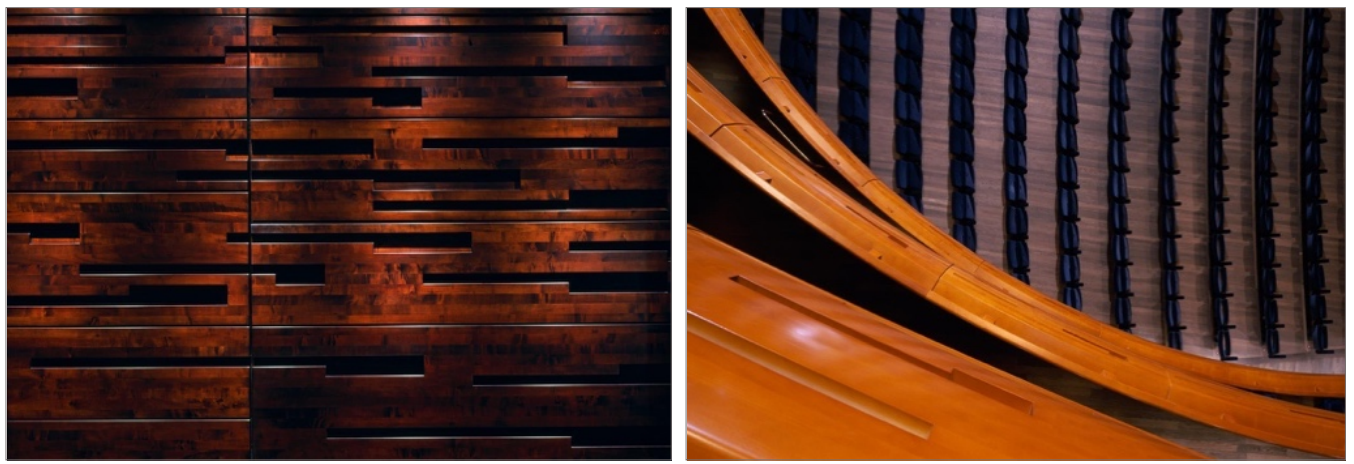

Şekil 26. Duvar kaplamalarında yer alan girinti ve çıkıntılar (URL-21)

\subsubsection{Sahne alanı}

Kopenhag Opera Binası'nın sahne alanı; ana sahne, sahneden asansörler ile bağlantı sağlanan sahne altı, yan ve arka sahneler ile üç adet sahne arkası bölümlerinden oluşmaktadır. Arka sahne bölümü, koro prova salonu ve orkestra prova salonu olarak da kullanılabilmektedir. Sahne alanının hemen üzerinde bulunan sofita kulesi 
performansın daha etkili bir şekilde izleyicilere sunulması için üstün teknik donanımlara sahip bir şekilde tasarlanmıştır. Sahne altında bulunan depo ve teknik birimlerin asansörle bağlantısı düşünülerek, sahnenin kurulmasında ve dekorun değiştirilmesinde sorumlu olan teknik görevlilerin iş yükü azaltılmıştır. Bu tasarım yaklaşımıyla zaman ve maliyet açısından da tasarruf sağlanmıştır (Şekil 27).
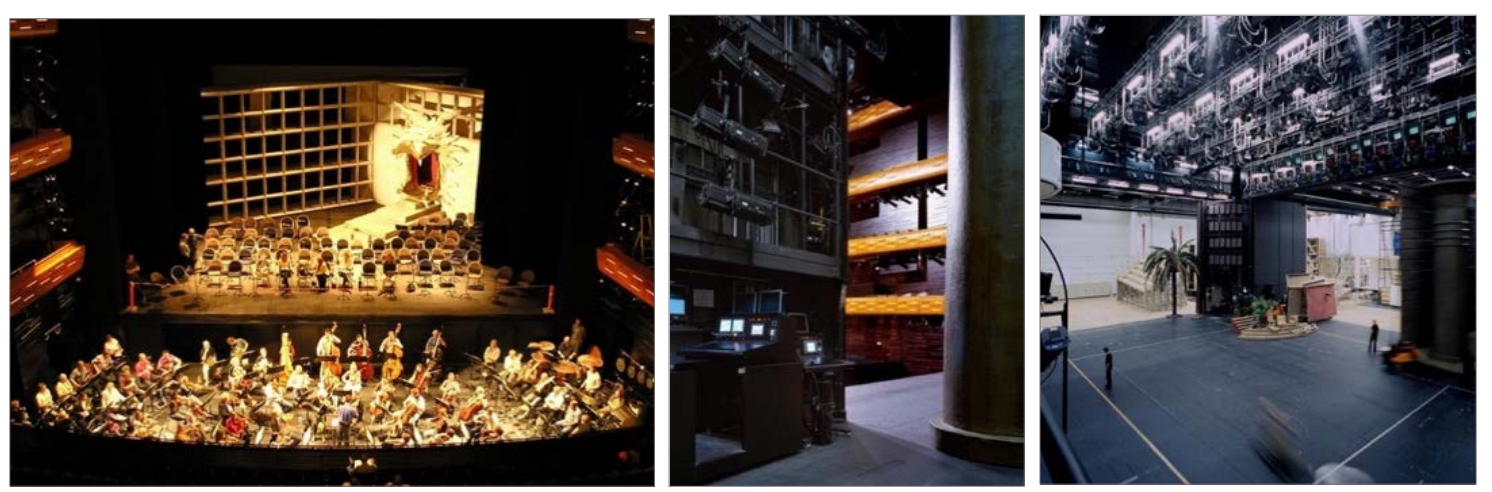

Şekil 27. Kopenhag Opera Binası sahne alanı (URL-25, URL-21, URL-21)

\subsubsection{Sahne arkası birimleri}

Kopenhag Opera Binası Danimarka Kraliyet Orkestrası'nın kullanımı için planlanmış sahne arkası birimlere sahiptir. Kraliyet Orkestrası'nın kullanımında olan prova odası, oditoryumun beş kat aşağısında yer almaktadır ve yapay olarak aydınlatılmış çatı pencereleri ile alana güneş ışığı alıyormuş görünümü verilmiştir. Duvarlar ve tavan ahşapla kaplanmıştır. Opera ve balenin her biri iki prova odasına sahiptir ve diğer küçük prova odaları müzisyenler ve koro için kullanılmaktadır (Şekil 28). Opera binasındaki soyunma odaları, ofisler ve atölyeler ile sahne depolama tesisleri bodrum katta yer almaktadır. En üst kattaki restoran ve teras, liman ve şehre karşı 180 derecelik panoramik bir bakış açısına sahiptir (URL-15).
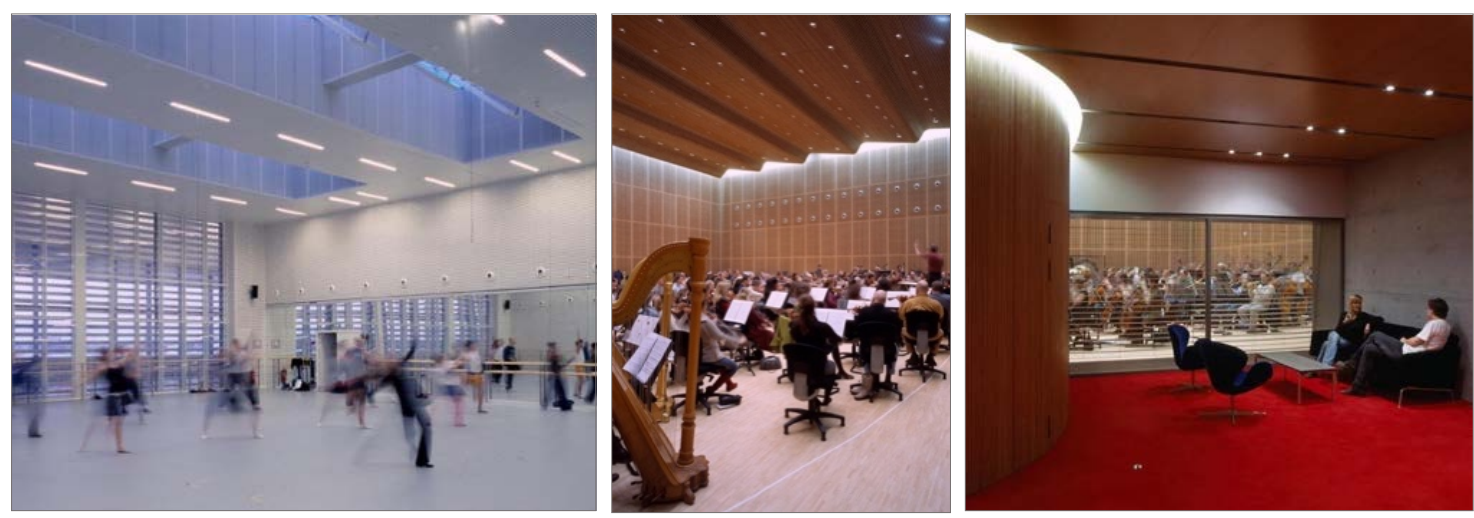

Şekil 28. Opera binasının prova odaları (URL-21)

\section{DEĞERLENDIRME VE SONUÇLAR}

Harbin ve Kopenhag Opera Binası benzerlik ve farklılıklarıyla tabloda karşılaştırmalı olarak değerlendirilmiştir. 
Tablo 1. Opera binalarının karşılaştırılmalı olarak sunumu

\section{Değer Harbin Opera Binası Kopenhag Opera Binası}

$\begin{array}{lll}\text { Bina, } & \bullet & \begin{array}{l}\text { Harbin Opera Binası'nın formu kentin } \\ \text { Kent ve }\end{array} \\ \text { iklim ve topografyasının özellikleri } \\ \text { Yakın } & \begin{array}{l}\text { dikkate alınarak tasarlanmıştır. } \\ \text { Çevre }\end{array} \text { Kültür adasında yer alan yapılar; } \\ \text { İlişkisi } & \begin{array}{l}\text { organik, akışkan form ve biçimlerle } \\ \text { birbirlerini tamamlar niteliktedir. }\end{array}\end{array}$

- Opera binası üç formun birlikteliğinden oluşmuştur. Bunlardan birincisi büyük opera salonunun bulunduğu en büyük hacimli form, ikincisi küçük tiyatro salonunun bulunduğu orta hacimli form ve üçüncüsü ise bilet satış ofislerinin bulunduğu küçük formdur.

- Organik forma sahip opera binası, Harbin Kültür Adası'nın odağında yer almakta ve yaklaşık 1.796 .804 $\mathrm{m}^{2}$ olan toplam arazide $80.000 \mathrm{~m}^{2}$ alan kaplamaktadır.

- Yapı, Çin'in Heilongjiang Eyaleti'nin en büyük şehri olan Harbin kentinde inşa edilmiştir.

- Songhua Nehri'nin suyundan faydalanılarak oluşturulmuş ve yapay göller ile desteklenmiş içerisinde kültürel ve sanatsal etkinliklerinin gerçekleştirilmesi planlanan Harbin Kültür Adası için tasarlanmıştır.

\section{Fuaye \\ Alanı}

- Yapının fuaye alanı, iki bölümden oluşmakta ve büyük opera salonu ile küçük tiyatro salonu arasındaki köprü ile birbirlerine bağlanmaktadır.

- Esnek çözümlerin uygulandığı mekanın fuaye alanında çoğunlukla beyaz renk kullanımıştır.

- Opera salonuna ulaşımı sağlayan heykelsi merdivenler ahşap malzemenin rengi ve dokusu ile mekana sıcaklık, görsel zenginlik ve dinamik bir etki kazandırmıştır.
- Opera binası tek bir formdan oluşmaktadır ve tüm birimler bu form içinde yer almaktadır.

- Genel olarak geometrik çizgilere sahip yapının, opera salonunu içinde taşıyan "conch" adlı kabuk organik formda tasarlanmış ve fuayede görsel etki oluşması sağlanmıştır.

- Yapının çatısı 32 metre bir konsol ile kanala doğru uzanmakta ve etkili bir görsellik sunmaktadır.

- Toplamda on dört kattan oluşan ve bu katlardan beşi zeminin altında bulunan opera binası $41,000 \mathrm{~m}^{2}$ alana sahiptir.

- Kopenhag Opera Binası, Danimarka'nın başkenti ve bir liman kenti olan Kopenhag'da inşa edilmiştir.

- Københavns Havn'ın batı yakasında etrafında 17 metrelik yapay kanal oluşturularak, küçük bir ada üzerinde tasarlanmıştır.

- Opera binasına giriş yapıldıktan sonra ziyaretçileri karşılayan fuaye alanına kanal manzarası eşlik etmektedir.

- Fuaye alanı; oturma birimleri, danışma, kafeterya-restoran, sirkülasyon alanları ve ıslak hacimlerden oluşmaktadır. Fuaye alanının zemininde ve opera salonuna bağlantıların saplandığı köprülerde beyaz renk kullanılmıştır. Akçaağaçtan tasarlanan opera salonunun kabuğu ise ahşap dokusu ve özel rengiyle mekana canlılık kazandırarak mekanın algısını güçlendirmiştir.

- Özellikle opera gösterilerine katılım zorunluluğu olmadan fuaye alanı tüm ziyaretçilere hizmet sunmaktadır.

- Opera salonuna köprülerle ulaşımı sağlayan fuaye alanı 
dört kat boyunca

yükselmektedir.

- Fuaye katlarındaki geniş balkonlarda ve köprülerde yürüyen ziyaretçiler için galeri boşluğu aracılığıyla katlar arasında görsel bağlantı kurulabilmektedir.

\begin{tabular}{|c|c|c|}
\hline $\begin{array}{l}\text { Opera } \\
\text { Salonu }\end{array}$ & $\begin{array}{l}\text { - Opera binası içerisinde } 1600 \text { koltuklu } \\
\text { büyük bir tiyatro salonu ve } 400 \text { kişilik } \\
\text { daha küçük bir tiyatro salonu } \\
\text { bulunmaktadır. } \\
\text { At nalı planı kullanılarak tasarlanmış } \\
\text { salon iki balkon katına sahiptir. Bu } \\
\text { katlarda localar da bulunmaktadır. }\end{array}$ & 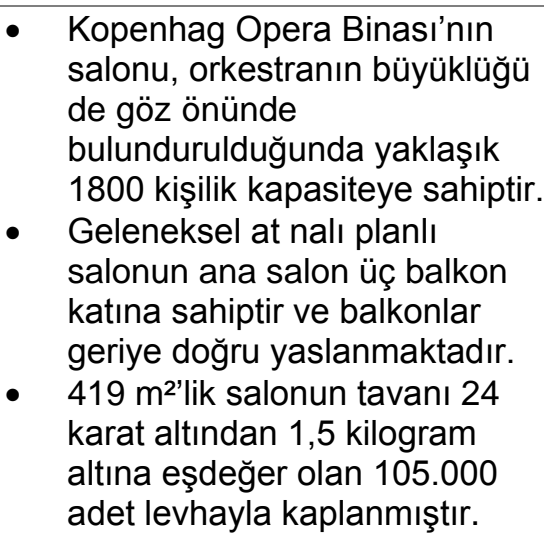 \\
\hline
\end{tabular}
\begin{tabular}{ll}
\hline Sahne & Harbin Opera Binası'nın sahne alanı; \\
Alanı & performansın gerçekleştirildiği ana
\end{tabular}

\section{Sahne}

Arkası Birimler sahne, iki adet yan sahne ve bir adet arka sahneden oluşmaktadır.

- Ana sahnenin üstünde yer alan sofita kulesi, sahne alanında gerçekleştirilecek olan performansın içeriğine göre alçalıp yükselebilen aydınlatma ve diğer teknik elemanlar ile donatılmıştır.

- Sahnenin hemen altında yer alan depo birimlerinden asansörler yardımıyla sahne dekorlarının taşınması sağlanmaktadır.
- Kopenhag Opera Binası'nın sahne alanı; ana sahne, sahneden asansörler ile bağlantı sağlayan sahne altı, yan ve arka sahneler ile üç adet arka sahne bölümlerinden oluşmaktadır.

- Sahne alanının hemen üzerinde bulunan sofita kulesi performansın daha etkili bir şekilde izleyicilere sunulması için üstün teknik donanımlara sahip bir şekilde tasarlanmıştır.
- Opera yapısının zemin katında yan sahnelere bitişik olarak tasarlanmış iki adet prova odası bulunmaktadır. Asma katta ise zemin kattaki prova odalarının yaklaşık üç katı büyüklüğünde üçüncü prova odası tasarlanmıştır.

- Asma katta yer alan prova odası performansları için hazırlık yapanlar tarafından kullanılmaktadır. Burası diğer prova odalarına göre daha esnek kullanıma sahiptir.

- Opera binasının dekor odası, soyunma odaları, ofisler ve atölyeler zemin katta; sahne depolama birimleri, otopark bodrum katta bulunmaktadır.
- Kopenhag Opera Binası'nın Danimarka Kraliyet Orkestrası için prova odası, oditoryumun beş kat aşağısında yer almakta ve yapay olarak aydınlatılmış çatı pencereleri ile alana güneş ışığı alıyormuş görünümünü verilmektedir.

- $\quad$ Opera ve balenin her biri iki prova odasına sahiptir ve diğer küçük prova odaları müzisyenler ve koro için kullanılmaktadır.

- Opera binasının dekor odası, soyunma odaları, ofisler ve atölyeler zemin katta; sahne depolama birimleri bodrum katında yer almaktadır. 
- Islak hacimler birinci katta, opera ve tiyatro salonlarının iki yanında kolay ulaşılabilir, fakat gizli bir planlama ile tasarlanmıştır.

- Prova odalarının her ikisinin hemen arkasında da ıslak hacimler planlanmıştır.

- $\quad$ Teras, zemin katta bulunan fuaye alanından 35 metre yükseklikte ziyaretçilere Harbin şehrinin panoramik manzarasını sunmak için tasarlanmıştır.
- Islak hacimler birinci katta fuaye alanının her iki ucunda kolay ulaşılabilir bir planlama ile tasarlanmıştır.

- Restoran ve teras, liman ve şehre karşı 180 derecelik panoramik bir bakış açısına sahip olacak şekilde opera binasının en üst katında tasarlanmıştır.

Günümüzdeki opera binalarının mimarisi, sanat alanındaki gelişmelerle paralellik göstermektedir. İşletilmesi güç olan bu yapıların çağın gereklerine göre düzenlendiği dikkat çekmektedir. İncelenen Harbin Opera Binası ve Kopenhag Opera Binası farklı coğrafyalarda gerçekleştirilmiş 21. yüzyıl yapılarıdır. Öncelikle her iki yapının da kültür ve sanat adına toplumlarına sahne sanatlarını yaygınlaştırmak, sevdirmek, halkın bu yönlü gereksinimlerini karşılamak ilkesi ile oluşturulduklarını söylemek mümkündür. Bunun yanı sıra tasarımlar planlanan bütçeye uygun olarak inşa edilmiştir. Dolayısıyla, hem ekonomik planlamaya uygun hem de estetik değerlerin ön planda tutularak tasarlanan ve inşa edilen bu eserler kentleri için birer işaret öğesi olmuştur. Ancak toplumların farklı öncelikleri yapıların form ve işlevsel tasarımlarının yönetilmesine kadar farklıııklar içerdiği de ayrı bir gerçek olarak karşımıza çıkmaktadır. Her iki opera binası, ait oldukları çağa olduğu kadar geleceğe yönelik tasarım ve teknolojik nitelikleri ile kendilerini şehir ikonu mertebesine taşımışlardır.

Harbin Opera Binası, Çin'in Heilongjiang Eyaleti'nin başkenti ve en büyük kenti olan Harbin'de, Songhua Nehri'nin güney yakasında geniş çaplı bir projenin bir kısmı olarak tasarlanmıştır. Konumu itibariye, farklı ulaşım ağlarının kesişim noktasında bulunan opera binası Harbin Kültür Adası'nın üzerinde yer almaktadır. Kentin yılın büyük bir zamanı karla kaplı olmasından yola çıkılarak "donan müziğin ritmi” metaforuyla tasarıma yön verilmiştir. Dolayısıyla hem opera binasında hem de fiziksel çevre düzenlemesinde renk, doku, malzeme, ışık özellikleri göz önünde bulundurularak doğal ortamıyla uyumlu organik formlar kullanılmıştır. Bu organik formlar, iç mekan ve yapı kabuğunda algılanmakla birlikte, etkili bir dış mekan görselini de ziyaretçilere sunmaktadır. Opera salonların bulunduğu kütlede, ana fuaye alanına gün ışığının girmesini sağlayan tavan ışıklıkları tasarlanmış ve çatı bir dizi cam piramit ile örtülerek opera binasına kışı çağrıştıran bir görünüm kazandırılmıştır. Fuaye alanından opera salonuna geçişi sağlayan ahşap merdivenler; beyaz rengin yoğun olarak kullanıldığı iç mekana rengi ve dokusuyla sıcaklık katmakla birlikte zemin, duvar ve çatıda kullanılan malzemeler ile etkileyici bir mekan oluşturmaktadır. Opera salonunda kullanılan ahşap kaplamalar, salonun zeminine ulaşmadan önce pek çok organik kıvrım ile balkon katlarını çevrelemektedir. Bu şekilde iç bükey ve dış bükey yüzeyler ile tasarlanan iç mekanda akustik özellikler dikkate alınarak tasarım gerçekleştirilmiştir. Opera salonunun sahnesi, arka birimleri ile birlikte performansların etkileyici bir şekilde sahnelenmesine imkan tanımaktadır.

Kopenhag Opera Binası Danimarka'nın Kopenhag kentinde; kara, deniz, tren ve havayolu da dahil olmak üzere ulaşım ağının yoğun olduğu Kopenhag Limanı'ndaki Dock Adası'nda inşa edilmiştir. Çağdaş bir teknikle tasarlanmış plaza üzerine eklenen 
32 metre uzunluğunda sundurma yapının oldukça dikkat çeken dış formunun oluşmasında etkili olmuştur. Çevredeki farklı noktalardan izlenebilen bina, cephesinde kullanılan cam malzemenin etkisiyle izleyicilerine gece ve gündüz farklı zenginlikte görsel şölenler sunmaktadır. Dış kabuğun asal bir geometride tasarlanmış olmasına rağmen, iç mekanda "conch" olarak adlandırılan ve fuayede yüzüyormuş izlenimi veren salonun dinamik ve organik forma sahip heykelsi kabuğu, fuayede görsel algıyı güçlendirmekte ve kullanıcıya mimari sürprizler sunmaktadır. Conch'un içinde tasarlanan solunun yüzeyi çok parçalı ahşap kaplamalarla kaplanarak salonun kaliteli bir akustik performansa sahip olması amaçlanmıştır. Sahne alanı; ana sahne, sahneden asansörler ile bağlantı sağlanan sahne altı, yan ve arka sahneler ile üç adet sahne arkası bölümlerinden oluşmaktadır. Arka sahne bölümü, koro prova salonu ve orkestra prova salonu olarak da kullanılabilmektedir. Bu bağlamda opera binası hem görsel hem de işlevsel anlamda kullanıcılarına kaliteli bir mekan sunmaktadır.

Sonuç olarak, Harbin Opera Binası ile Kopenhag Opera Binası 21. yüzyıl tasarım konseptleri ile inşa edilme tekniklerinin bir araya geldiği eserler olarak karşımıza çıkmaktadır. Opera binaları kentsel ölçekteki yerleşimleri, inşa edildikleri kentsel noktaları, formları, fuaye alanları, opera salonları ile ziyaretçileri kendine çeken, merak uyandıran, mekanların deneyimlenmesi ile farklı duygusal ve duyusal hislerin oluşmasında etkili oldukları düşünülmektedir. Farklı kültürlerin, kimliklerin buluşma mekanı olan bu binalar, farklı ulaşım ağlarının kesişim noktasında, çevresindeki doğal ortamla uyumlu bir şekilde tasarlanmıştır. Formları sayesinde etkili dış mekan kullanımına sahip olan yapıların kamuya açık alanlardan gözlemlenebilen dış cephelerinde ve fuaye alanlarındaki malzemeler hem görsel hem de fiziksel açıdan etkileyici özelliklere sahiptir. Opera salonları ve sahneleri yardımcı birimleri sayesinde oldukça esnek kullanıma sahip olup, bu durum gösterilerin etkileyici bir şekilde sahnelenmesine imkan sağlamaktadır. Opera binaları tüm bu özellikleri ile birlikte, özellikle mimarlar ve mimarlık öğrencileri için örnek nitelik taşımaktadır.

\section{KAYNAKÇA}

Bilgiç, B., "Harbin Opera Evi", 2018, Http://Www.Arkitera.Com/Proje/7177/HarbinOpera-Evi.

Fuat, M., "Tiyatro Tarihi”, Varlık Yayınları, İstanbul, 1984, s.65.

Garber, R., "Mad Architects The Harbin Opera House", 2017. https://onlinelibrary.wiley.com/doi/pdf/10.1002/ad.2183. s.130-135.

Greenwald, H. M., "Opera”, Oxford Handbook, Londra, 2014, s.1.

Karlson, C., "Rotch Case Study: Royal Danish Playhouse \& Copenhagen Opera House", 2011.

http://www.chriskarlson.com/blog/2011/9/25/rotch-case-study-royal-danish-playhousecopenhagen-opera-hou.html,

Mollard, M., "Harbin Opera House in China By Mad Architects, The Architectural Review", 2015. https://www.architectural-review.com/today/harbin-opera-house-inchina-by-mad-architects/8691096.article,

Nutku, Ö., “Dünya Tiyatrosu Tarihi I”, Remzi Kitabevi, İstanbul, 1985, s.142. 
Rossing, T. D., "Springer Hanbook of Acoustics", Springer Science + Business Media, New York, 2007, s.15.

Şahin, G., "Mad Architects - Harbin Opera House", 2015.

Http://Www.Mimarizm.Com/Mimari-Projeler/Muze-Ve-Kultur/Mad-Architects-HarbinOpera-House 124544,

URL-1, Etimoloji Sözlüğü. https://www.etimolojiturkce.com/kelime/opera. Erişim Tarihi: 18.11.2018, Saat: 09:28.

URL-2, http://www.i-mad.com, Erişim Tarihi: 12.12.2018, Saat: 23:11.

URL-3,https://www.architecturalrecord.com/articles/11368-harbin-opera-house, Seno, A., A. 2015. Harbin Opera House, Erişim Tarihi: 18.11.2018, Saat: 21:18.

URL-4,https://www.detail-online.com/article/a-snowdrift-of-steel-harbin-opera-house27120/, Erişim Tarihi: 16.11.2018, Saat: 17:03.

URL-5,https://www.designboom.com/architecture/mad-architects-harbin-opera-housechina-iwan-baan-photography-ma-yansong-04-28-2016/, Erişim Tarihi: 16.11.2018, Saat: 16:13.

URL-6, https://pldturkiye.com/harbin-opera-binasi-projesi/, Erişim Tarihi: 16.11.2018, Saat: 15:20.

URL-7,https://www.recre8tion.com/HARBIN-OPERA-HOUSE, Erişim Tarihi: 15.11.2018, Saat: 20:17.

URL-8,http://www.kilsanblog.com/mimarlik-farkli-ilginc-yapilar/harbin-opera-binasi/, Erişim Tarihi: 17.11.2018, Saat: 21:10.

URL-9,https://www.archdaily.com/430314/harbin-cultural-center-madarchitects/5238c694e8e44e24570001e3-harbin-cultural-center-mad-architects-photo, Erişim Tarihi: 18.11.2018, Saat: 22:17.

URL-10,https://earth.google.com/web, Erişim Tarihi: 18.11.2018, Saat: 23:49

URL-11,http://www.huftonandcrow.com/projects/gallery/harbin-opera-housel, Erişim Tarihi: 14.11.2018, Saat: 09:19.

URL-12,https://tr.wikipedia.org/wiki/Kopenhag, Erişim Tarihi: 18.11.2018, Saat: 12:17.

URL-13,https://www.themagger.com/dunyadaki-modern-opera-binalari/, Erişim Tarihi: 12.11.2018, Saat: 16:20.

URL-14,http://www.kopenhag.net/gezelim-gorelim/aktiviteler/bale-operatiyatro/danimarka-kraliyet-opera-evi-2, Erişim Tarihi: 12.11.2018, Saat: 22:03.

URL-15,https://arcspace.com/feature/copenhagen-opera-housel, Erişim Tarihi: 13.11.2018, Saat: 23:18. 
URL-16,http://www.arkitera.com/haber/4713/iki-sehrin-hikayesi, Emine Merdim YILMAZ, 2010. Erişim Tarihi: 12.11.2018, Saat: 22:13.

URL-17,https://www.citylab.com/design/2013/07/henning-larsens-greatest-buildingwas-also-his-greatest-failure/6069/, Erişim Tarihi: 14.11.2018, Saat:10:29.

URL-18,https://www.burohappold.com/wp-content/uploads/2016/05/Danish-NationalOpera-House1.pdf, Erişim Tarihi: 14.11.2018, Saat:13:19.

URL-19, http://bladt.pl/ez/master/index.php?/en/Produkcja/Building-and-Constraction, Erişim Tarihi: 14.11.2018, Saat: 12:45.

URL-20, googleearth, Erişim Tarihi: 12.11.2018, Saat: 22:28.

URL-21,http://arcdog.com/portfolio/copenhagen-opera-house/, Erişim Tarihi: 12.11.2018, Saat: 23:28.

URL-22,https://www.architectural-review.com/essays/typology/typology-operahouses/8653735.article, Erişim Tarihi: 12.11.2018, Saat: 10:20

URL-23,https://www.e-architect.co.uk/copenhagen/copenhagen-opera-house, Erişim Tarihi: 18.11.2018, Saat: 19.11.

URL-24,http://www.swegon.com/da/Air-Innovation/Internationaleprojekter1/Other/Copenhagen-Opera-House-Denmarkl, Erişim Tarihi: 18.11.2018, Saat: 21:45.

URL-25,https://www.arup.com/projects/copenhagen-opera-house, Erişim Tarihi: 12.11.2018, Saat:18:26

Yener, F., “100 Opera”, Doğan Kardeş Yayıncılık, İstanbul, 1964, s.5-11.

Yıldız, P., "Sahne Ve Seyirci Etkileşiminin Tarihsel Gelişiminde Göstergebilimsel Açıdan Bir Analiz", 2005, s.430-435.

Worrall, J., "Harbin Opera House", 2016.

Https://Www.İconeye.Com/Architecture/Features/Item/12384-Harbin-Opera-House, 